\title{
Dawson-Type Polyoxometalate Incorporated into Nanoporous MIL-101(Cr): Preparation, Characterization and Application for Ultrafast Removal of Organic Dyes
}

\author{
Afsoon Jarrah and Saeed Farhadi ${ }^{*}$ \\ Department of chemistry, Lorestan University, Khorramabad, 68151-44316, Iran \\ * Corresponding author: E-mail: sfarhadi1348@yahoo.com \\ Tel: +986633120611, fax: +986633120618 \\ Received: 06-01-2018
}

\begin{abstract}
In this work, Dawson-type $\mathrm{K}_{6} \mathrm{P}_{2} \mathrm{~W}_{18} \mathrm{O}_{62}$ polyoxometalate salt (abbreviated as $\mathrm{P}_{2} \mathrm{~W}_{18}$ ) was successfully encapsulated into mesoporous MIL-101(Cr) metal organic framework. The as-prepared $\mathrm{P}_{2} \mathrm{~W}_{18} @ \mathrm{MIL}-101(\mathrm{Cr})$ nanohybrid was characterized by FT-IR spectroscopy, XRD, Raman spectroscopy, EDX, SEM, zeta potential measurements and BET surface area. The results demonstrated the successful loading of $\mathrm{K}_{6} \mathrm{P}_{2} \mathrm{~W}_{18} \mathrm{O}_{62}(\sim 36 \mathrm{wt} . \%)$ into porous MIL-101(Cr) framework. Compared with the pristine MIL-101(Cr), the encapsulated sample demonstrated a significant decrease in both surface area and pore volume owing to the insertion of large Dowson-type POM into the cages of MOF. The resulting $\mathrm{P}_{2} \mathrm{~W}_{18} @ \mathrm{MIL}-101(\mathrm{Cr})$ was applied as a new adsorbent to remove methylene blue (MB), Rhodamine B (RhB) and methyl orange (MO) organic dyes from aqueous solutions. The effect of effective parameters such as adsorbent dosage, dye concentration, $\mathrm{pH}$, and the temperature was studied on the dye removal process. Furthermore, the selective adsorption of the nanohybrid was investigated towards $\mathrm{MB} / \mathrm{MO}, \mathrm{MB} / \mathrm{RhB}, \mathrm{MO} / \mathrm{RhB}$ and $\mathrm{MB} / \mathrm{MO} / \mathrm{RhB}$ mixed dye solutions. The nanohybrid showed rapid and selective adsorption for cationic $\mathrm{MB}$ and $\mathrm{RhB}$ dyes from mixed dye solutions. The results indicated that the dye adsorption followed Langmuir isotherm. The thermodynamic data showed that the adsorption is an endothermic process. This nanohybrid can function as a recyclable efficien adsorbent for the rapid removal of various cationic textile dyes from aqueous solutions.
\end{abstract}

Keywords: Dawson-type polyoxometalate; MIL-101(Cr); Metal organic framework (MOF); Nanohybrid; Dye adsorption.

\section{Introduction}

Metal organic frameworks (MOFs) are crystalline porous materials whose structures are defined by metal ions or metallic clusters that are connected to bi- or multipodal organic linkers. ${ }^{1}$ Nowadays, MOFs have attracted significant research attention in many attractive fields because of their high surface areas, tunable structures and pore sizes, low framework densities, and high pore volumes relative to other porous matrices. ${ }^{2,3}$ These unique and outstanding features of MOFs have resulted in a vast range of promising potential applications such as catalysis, ${ }^{4}$ luminescence, ${ }^{5}$ magnetism, ${ }^{6}$ drug delivery, ${ }^{7-10}$ chemical sensing, ${ }^{11}$ ion exchange, ${ }^{12}$ pollutant removal in aqueous media, ${ }^{13-16}$ and gas storage and separation. ${ }^{17,18}$ Furthermore, owing to their large surface areas and high pore volumes, MOFs can be utilized as hosts for encapsulating large molecules to construct novel multifunctional materials. ${ }^{19}$
Polyoxometalates (POMs) are a class of compounds formed by bulky clusters of transition metal oxide anions and have attracted intensive attention due to their earth-abundant source, rich topology and versatility, controllable shape and size, oxo-enriched surfaces, highly electronegative etc, with various applications in many fields, such as catalysis, optics, magnetism, biological medicine as well as dye adsorption. ${ }^{20}$ The disadvantages of low surface area $\left(<10 \mathrm{~m}^{2} \mathrm{~g}^{-1}\right)$ and high solubility in the reaction system limit their the recovery and reuse on a large scale. To overcome this limitation, permanent heterogenization of these homogeneous catalysts into various host supports such as such as SBA-15, MCM-41, and $\mathrm{ZrO}_{2}$ has been reported. ${ }^{21,22}$ However, these systems tend to have limited POM loading and present some leaching, and the supported POMs show a tendency for agglomeration. Therefore, it is of great importance to look for more appro- 
priate materials to immobilize POMs. MOF is an attractive host matrix for the encapsulation of POM taking into account the benefit of its (i) large mesocages for the encapsulation of POM molecules, (ii) good POM dispersion, (iii) high surface area, (iv) a simple and efficient one-pot synthesis of the formulation and (v) a relatively high framework stability. To date, the encapsulation of Keggin-type POMs in MOFs has been reported, and research on their adsorption performance of the POM@MOFs has been performed. ${ }^{23-31}$

In this work, a novel nanohybrid material based on Dawson-type polyoxometalate $\left(\mathrm{K}_{6} \mathrm{P}_{2} \mathrm{~W}_{18} \mathrm{O}_{62} ; \mathrm{P}_{2} \mathrm{~W}_{18}\right)$ encapsulated in metal organic framework MIL-101(Cr) was prepared by a simple hydrothermal method. The resulting $\mathrm{P}_{2} \mathrm{~W}_{18} @ \mathrm{MIL}-101(\mathrm{Cr})$ material was characterized by several techniques in detail, and its ability was evaluated in the adsorptive removal of organic dyes under ambient conditions. The results showed that the $\mathrm{P}_{2} \mathrm{~W}_{18} @ \mathrm{MIL}-101(\mathrm{Cr})$ hybrid is an effective adsorbent for ultrafast removal of cationic dyes such as methylene blue (MB)and rhodamine $\mathrm{B}(\mathrm{RhB})$ from aqueous solutions. The effects of dye concentration, $\mathrm{pH}$, adsorbent dosage, and temperature were investigated on the adsorption process. Moreover, the kinetics, thermodynamic, and isothermal properties the adsorption process were also studied.

\section{Experimental}

\section{1. Materials}

Chromium(III) nitrate $\left(\mathrm{Cr}\left(\mathrm{NO}_{3}\right)_{3} .9 \mathrm{H}_{2} \mathrm{O}, 99 \%\right)$, terephthalic acid $\left(\mathrm{H}_{2} \mathrm{BDC}, 98 \%\right)$, sodium tungstate $\left(\mathrm{Na}_{2} \mathrm{WO}_{4} 2 \mathrm{H}_{2} \mathrm{O}, 99 \%\right)$, phosphoric acid $\left(\mathrm{H}_{3} \mathrm{PO}_{4}, 85 \%\right)$ were provided from Sigma-Aldrich. All organic solvents were purchased from Merck or Aldrich and were utilized without further purification. Potassium chloride $(\mathrm{KCl}$, $98 \%)$, hydrochloric acid $(\mathrm{HCl}, 35 \%)$, methyl orange ( $\mathrm{MO}$, $\mathrm{C}_{14} \mathrm{H}_{14} \mathrm{~N}_{3} \mathrm{NaO}_{3} \mathrm{~S}, 98 \%$ ), methylene blue ( $\mathrm{MB}, \mathrm{C}_{16} \mathrm{H}_{18} \mathrm{ClN}_{3} \mathrm{~S}$, 98\%) and Rhodamine $\mathrm{B}\left(\mathrm{RhB}, \mathrm{C}_{28} \mathrm{H}_{31} \mathrm{ClN}_{2} \mathrm{O}_{3}, 98 \%\right)$ were purchased from Merck Chemical Co.

\section{2. Synthesis of MIL-101(Cr) Metal Organic Framework}

MIL-101(Cr) was synthesized by a hydrothermal route in aqueous media and in the absence of hydrofluoric acid. ${ }^{32} \mathrm{Cr}\left(\mathrm{NO}_{3}\right)_{3}{ }_{9} \mathrm{H}_{2} \mathrm{O}(2.4 \mathrm{~g})$, terephthalic acid (0.98 g) were blended in $29 \mathrm{ml}$ distilled water and mixed at room temperature for time 10-20 min was stirred. The suspension to a $50 \mathrm{ml}$ Teflon-lined autoclave was transferred and in oven was heated for $24 \mathrm{~h}$ at $200{ }^{\circ} \mathrm{C}$. After slowly cooling at room temperature, the green solid was filtered and washed with DMF at $60^{\circ} \mathrm{C}$ for $3 \mathrm{~h}$ and then with ethanol at $70{ }^{\circ} \mathrm{C}$ for $2.5 \mathrm{~h}$ to remove the unreacted terephthalic acid $\left(\mathrm{H}_{2} \mathrm{BDC}\right)$. Finally, the green solid was separated by centrifugation and was dried at room temperature.

\section{3. Synthesis of Dawson-Type $\mathrm{K}_{6} \mathrm{P}_{2} \mathrm{~W}_{18} \mathrm{O}_{62}$ Polyoxometalate}

The Dawson-type $\mathrm{K}_{6} \mathrm{P}_{2} \mathrm{~W}_{18} \mathrm{O}_{62}$ polyoxometalate was prepared according to the reported method. ${ }^{33} \mathrm{~A}$ sample of $\mathrm{Na}_{2} \mathrm{WO}_{4} 2 \mathrm{H}_{2} \mathrm{O}$ (300 g; $0.91 \mathrm{~mol}$ ) dissolved in $350 \mathrm{~mL}$ distilled water was acidified by fractional addition of $\mathrm{HCl} 4 \mathrm{M}$ $(250 \mathrm{~mL} ; 1.00 \mathrm{~mol})$ under vigorous stirring. When the cloudy solution becomes limpid again, $\mathrm{H}_{3} \mathrm{PO}_{4} 4 \mathrm{M}(250$ $\mathrm{mL} ; 1.00 \mathrm{~mol}$ ) was added slowly. The pale yellow and limpid solution was refluxed for at least $24 \mathrm{~h}$. After this reaction time, the yellowcolour of the solution had become more intense. This solution was allowed to cool to room temperature and was then treated with $150 \mathrm{~g} \mathrm{KCl}$. The precipitate which appeared was filtered off and air-dried by aspiration. This crude material was dissolved in $650 \mathrm{~mL}$ distilled water, and the solution was, eventually, filtered to remove insoluble impurities. The limpid solution was then heated at $80^{\circ} \mathrm{C}$ for $72 \mathrm{~h}$. After this period of time, the solution was allowed to cool to room temperature before being placed finally in a refrigerator at $4{ }^{\circ} \mathrm{C}$. After a few days, well-behaved yellow crystals of $\alpha-\mathrm{K}_{6} \mathrm{P}_{2} \mathrm{~W}_{18} \mathrm{O}_{62} \quad 14 \mathrm{H}_{2} \mathrm{O}$ were collected (232.5 g; 95\%).

\section{4. Synthesis of $\mathrm{P}_{2} \mathrm{~W}_{18} @ \mathrm{MIL}-101$ (Cr) Nanohybrid}

The $\mathrm{P}_{2} \mathrm{~W}_{18} @ \mathrm{MIL}-101(\mathrm{Cr})$ nanohybrid was fabricated as follows: $\mathrm{Cr}\left(\mathrm{NO}_{3}\right)_{3} 9 \mathrm{H}_{2} \mathrm{O}(2.0 \mathrm{~g}, 5 \mathrm{mmol})$, terephthalic acid $(0.83 \mathrm{~g}, 5 \mathrm{mmol}), \alpha-\mathrm{K}_{6} \mathrm{P}_{2} \mathrm{~W}_{18} \mathrm{O}_{62} 14 \mathrm{H}_{2} \mathrm{O}(2.0 \mathrm{~g}, 0.7$ $\mathrm{mmol}$ ) in $20 \mathrm{~mL}$ of distilled water were dispersed for 15 $\mathrm{min}$ by sonicating. The suspension color with a $\mathrm{pH}$ of 2.58 became dark blue. The suspension to a $50 \mathrm{ml}$ Teflon-lined autoclave was transferred and heated at $200{ }^{\circ} \mathrm{C}$ for $18 \mathrm{~h}$ without stirring under autogenous pressure. Then, green powder was separated by centrifugation, washed five times with distilled water, one-time ethanol, and acetone, and then was dried at room temperature. The ICP-AES results indicated that the loading amount of $\mathrm{P}_{2} \mathrm{~W}_{18}$ in the as-prepared $\mathrm{P}_{2} \mathrm{~W}_{18} / \mathrm{MIL}-101$ nanocomposite was estimated to be $36 \mathrm{wt} \%$.

\section{5. Methods of Characterization}

FT-IR was registered using a Shimadzu-8400S (Japan) spectrometer with temperature controlled high sensitivity detector (DLATGS detector) in the wavenumber range of 500-4000 $\mathrm{cm}^{-1}$. Powder X-ray diffraction (XRD) patterns were recorded at room temperature on a Rikagu $\mathrm{D}$-max X-Ray diffractometer using $\mathrm{Cu} \mathrm{Ka}$ radiation $(\lambda=$ $1.5418 \AA$ ). The morphological properties nanohybrid acquired by scanning electron microscopy (SEM, MIRA3 TESCAN) along with the energy-dispersive X-ray analysis (EDX). Specific surface area of samples was determined by the $\mathrm{N}_{2}$ adsorption-desorption Brunauer-Emmett-Teller (BET) method at $77 \mathrm{~K}$ (Micrometrics PHS-1020). Zeta po- 
tential measurements were carried out by using a Nano Zeta sizer system (Malvern, UK) equipped with a standard $628 \mathrm{~nm}$ laser. Raman spectrum was recorded on a SENTERRA 2009 system using laser wavelength of $758 \mathrm{~nm}$. The adsorption process of dyes was evaluated on a Varian Cary 100 spectrophotometer. UV-Vis spectrophotometer. The loading amount of HPW in the composite adsorbent and the concentrations of $\mathrm{Cr}$ and $\mathrm{W}$ metals in the filtrates and solutions after recovering adsorbent were determined was determined by inductively coupled plasma atomic emission spectrometer (Perkinelmer ICP-AES, USA).

\section{6. Dye Adsorption Tests}

Experiments were carried out to investigate the adsorption attributes and parameters affecting the adsorption of the dyes. Firstly, stock solutions $\left(200 \mathrm{mg} \mathrm{L}^{-1}\right)$ of $\mathrm{RhB}, \mathrm{MB}$, and $\mathrm{MO}$ dyes were prepared by dissolving them in distilled water. Then, the stock solution was constructed in the form of dye solutions of $\mathrm{MB}, \mathrm{MO}$, and $\mathrm{RhB}$, with consecutive dilutions using distilled water. The adsorbent $(30 \mathrm{mg}$ ) was added into $30 \mathrm{~mL}$ of the aqueous solution of different dyes with an initial concentration of $25 \mathrm{mg} \mathrm{L}^{-1}$ such as $\mathrm{MB}, \mathrm{RhB}$, and MO. In order to prevent degradation of the dyes, the containers holding the dye solution were wrapped in dark paper during the adsorption tests to protect the dye from light. The mixture was stirred gently at a speed of $300 \mathrm{rpm}$ at $25^{\circ} \mathrm{C}$ for 0.5 to $10 \mathrm{~min}$, and the adsorbent was separated by centrifugation. The residual dye concentrations were determined at the maximum wavelength of $463 \mathrm{~nm}$ for MO, $553 \mathrm{~nm}$ for RhB and 664 $\mathrm{nm}$ for MB by using a UV-Vis spectrophotometer. Similar experiments were performed to study the adsorption of $\mathrm{MB}$ with different dosages of the adsorbent; $(10,20,30$, and $40 \mathrm{mg}$ ). In addition, different initial concentrations of MB solution (25, 50, 75, 100, 125, 150, 175, and $200 \mathrm{mg}$ $\mathrm{L}^{-1}$ ) were used for studying the capability of the synthesized nanohybrid. Also, the nanohybrid was poured into mixtures of $\mathrm{MO} / \mathrm{RhB}, \mathrm{MO} / \mathrm{MB}, \mathrm{RhB} / \mathrm{MB}$, and $\mathrm{MB} / \mathrm{RhB} /$ MO (v: v 1/1, $30 \mathrm{~mL}, 25 \mathrm{mg} \mathrm{L}^{-1}$ ) to study the selective adsorption activity of adsorbent. The effects of initial $\mathrm{pH}$ $(2-10)$ and temperature $\left(25-95^{\circ} \mathrm{C}\right)$ of $\mathrm{MB}$ dye solution on the adsorption capacity were also investigated. The equilibrium adsorption capacity $\mathrm{q}_{\mathrm{e}}(\mathrm{mg} / \mathrm{g})$ and the dye removal efficiency (R\%) were calculated according to Equations (1) and (2), respectively:

$$
\begin{aligned}
& q e(m g / g)=\frac{\left[V\left(C_{0}-C_{e}\right)\right]}{m} \\
& R \%=\left[\frac{\left(C_{0}-C_{t}\right)}{C_{0}}\right] \times 100
\end{aligned}
$$

Where $\mathrm{C}_{0}$ and $\mathrm{C}_{\mathrm{t}}\left(\mathrm{mg} \mathrm{L}^{-1}\right)$ are the dye concentrations at initial and $t$ times, respectively. $\mathrm{V}$ (in $\mathrm{L}$ ) is the volume of the dye solution and $\mathrm{m}$ (in $\mathrm{g}$ ) indicates the mass of the ad- sorbent in the adsorption process. Thermodynamic studies were conducted at different temperatures $\left(25-75^{\circ} \mathrm{C}\right)$ to investigate the dye adsorption. In all aqueous solutions containing dye and $\mathrm{P}_{2} \mathrm{~W}_{18} / \mathrm{MIL}-101$ adsorbent, the residual concentrations of $\mathrm{Cr}$ and $\mathrm{W}$ after removing the adsorbent were detected to be less than $0.1 \%$ by the ICP-AES analysis of the reaction mixtures.

\section{7. Desorption Studies}

Nanohybrid after each adsorption test of the MB dye solution using centrifugation was separated and several times with mixed distilled water, $\mathrm{NaCl}(0.1 \mathrm{M})$, and ethanol was washed and at room temperature was dried and reused for the next adsorption experiment.

\section{Results and Discussion}

\section{1. Characterization of Nanohybrid}

Among various MOFs, MIL-101(Cr) is one of the most promising porous materials for future energy and environmental applications, owing to its superior physicochemical properties including high hydrothermal/chemical stability and desirable textural properties. The structure of MIL-101(Cr) was formed of Cr(III) clusters interconnected by terephthalate (BDC) anions. The framework of MIL-101(Cr) was composed of two types of mesoporous cages with diameters of 29 and $34 \AA$ accessible through two types of microporous windows. The smaller cages have pentagonal windows with a free opening of $12 \AA$, while the larger cages possess both pentagonal and hexagonal windows with a $14.7 \AA$ by $16 \AA$ free aperture. ${ }^{34,35}$ In this work, the Dawson-type POM was encapsulated into the porous MIL-101(Cr) framework by a simple hydrothermally reaction of $\mathrm{K}_{6} \mathrm{P}_{2} \mathrm{~W}_{18} \mathrm{O}_{62}$ (abbreviate as $\mathrm{P}_{2} \mathrm{~W}_{18}$ ), $\mathrm{Cr}\left(\mathrm{NO}_{3}\right)_{3} 9 \mathrm{H}_{2} \mathrm{O}$ and terephthalic acid $\left(\mathrm{H}_{2} \mathrm{BDC}\right)$. at $180^{\circ} \mathrm{C}$ for $24 \mathrm{~h}$. Scheme 1 shows the general preparation procedure of the $\mathrm{P}_{2} \mathrm{~W}_{18} @ \mathrm{MIL}-101(\mathrm{Cr})$ nanohybrid. During the formation of the MIL-101 (Cr) framework, $\mathrm{K}_{6} \mathrm{P}_{2} \mathrm{~W}_{18} \mathrm{O}_{62}$ molecules are encapsulated into the MIL-101 (Cr) framework to create a new hybrid with the formula of $\mathrm{P}_{2} \mathrm{~W}_{18} @$ MIL-101(Cr). ${ }^{36}$ The structure and composition of the

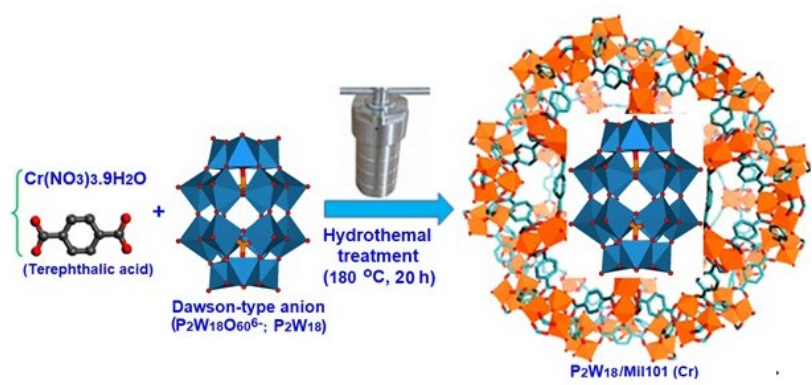

Scheme 1. Schematic illustration for the preparation of $\mathrm{P}_{2} \mathrm{~W}_{18} @$ MIL101(Cr). 
as-obtained hybrid nanomaterial was further characterized by FT-IR, Raman, XRD, EDX, SEM, and BET surface area analyses

FT-IR spectra of MIL-101 (Cr), $\mathrm{P}_{2} \mathrm{~W}_{18}$ and $\mathrm{P}_{2} \mathrm{~W}_{18} @$ MIL-101(Cr) samples were recorded in the range of 400$4000 \mathrm{~cm}^{-1}$, as shown in Figure 1. As shown in Figure 1(a), the characteristic absorption peaks of MIL-101(Cr) sample are observed in the region from 1400 to $1600 \mathrm{~cm}^{-1}$, which could mainly originate from the carboxylate groups (-COO) vibrations and are identical to those of reported data in the literatures. ${ }^{37}$ The two sharp peaks at 1636 and $1396 \mathrm{~cm}^{-1}$ are assigned to asymmetric and symmetric vibrations of -COO groups, respectively, confirming the presence of the dicarboxylate linker within the sample. The presence of free terephthalic acid $\left(\mathrm{H}_{2} \mathrm{BDC}\right)$ impurities in MIL-101 sample was evidenced by absorption bands at 1680 and $1510 \mathrm{~cm}^{-1}$. It should be mentioned that the preparation of MIL-101 with high purity is very difficult due to the presence of trapped $\mathrm{H}_{2} \mathrm{BDC}$ residues within the pores of MIL-101. Figure 1(b) shows the characteristic bands of Dowson-type $\mathrm{P}_{2} \mathrm{~W}_{18}$ at 1091, 960, 912, and $775 \mathrm{~cm}^{-1}$ which are related to $\mathrm{P}-\mathrm{O}, \mathrm{W}=\mathrm{O}_{\mathrm{t}}, \mathrm{W}-\mathrm{O}_{\mathrm{b}}-\mathrm{W}$ and $\mathrm{W}-\mathrm{O}_{\mathrm{c}}-\mathrm{W}$ bonds, respectively. ${ }^{38-40}$ As displayed in Figure 1(c) , the absorption bands of $\mathrm{P}_{2} \mathrm{~W}_{18}$ at 1090, 963, 912, and $775 \mathrm{~cm}^{-1}$ corresponding to the $\mathrm{P}-\mathrm{O}, \mathrm{W}=\mathrm{Ot}, \mathrm{W}-\mathrm{O}_{\mathrm{b}}-\mathrm{W}$ and $\mathrm{W}-\mathrm{O}_{\mathrm{c}}-\mathrm{W}$ bonds and the vibrational bands of MIL-101 lo-

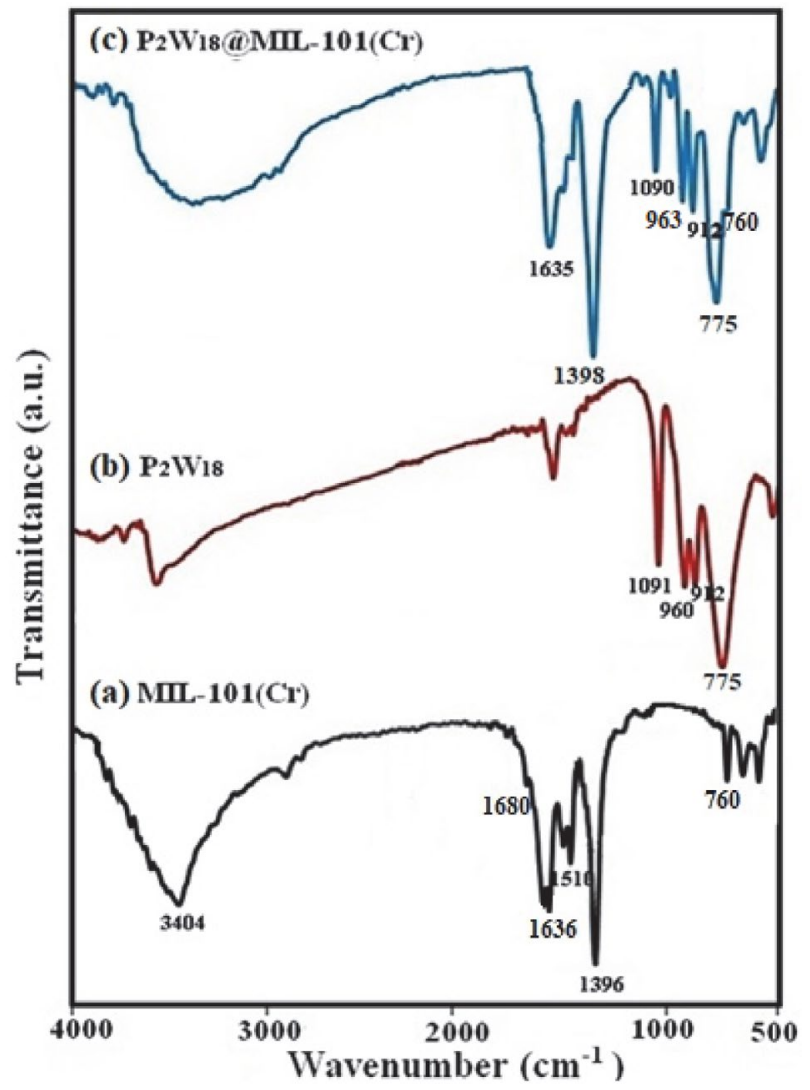

Figure 1. FT-IR spectra of (a) MIL-101 (Cr), (b) $\mathrm{P}_{2} \mathrm{~W}_{18}$ and (c) $\mathrm{P}_{2} \mathrm{~W}_{18} @ \mathrm{MIL101}(\mathrm{Cr})$ samples. cated around 1635,1398 , and $760 \mathrm{~cm}^{-1}$ were all observed in the FT-IR spectrum of $\mathrm{P}_{2} \mathrm{~W}_{18} @ \mathrm{MIL}-101(\mathrm{Cr})$ nanocomposite, which demonstrates the presence of $\mathrm{P}_{2} \mathrm{~W}_{18}$ and MIL-101 in the $\mathrm{P}_{2} \mathrm{~W}_{18} @$ MIL-101 composite. However, there are slightly shifted peaks compared with the pure $\mathrm{P}_{2} \mathrm{~W}_{18}$. These shifts imply that a strong interaction exists between the Dawson-type anion and MIL-101(Cr) MOF. ${ }^{37}$

XRD patterns of the MIL-101(Cr) and $\mathrm{P}_{2} \mathrm{~W}_{18} @$ MIL10 (Cr) samples are presented in Figure 2. The XRD pattern of the pristine MIL-101(Cr) is presented in Figure 2(a). The main diffraction peaks corresponding to reflection planes are indexed, which are consistent with the peak positions reported for standard MIL-101(Cr) structure, indicating that the synthesized material has the MIL$101(\mathrm{Cr})$ phase with good crystallinity. ${ }^{41}$ The peak positions of $\mathrm{P}_{2} \mathrm{~W}_{18} @ M I L-10(\mathrm{Cr})$ in Figure 2(b) are matched well with the parent MIL-101(Cr). As can be seen, some diffraction peaks related to $\mathrm{P}_{2} \mathrm{~W}_{18}$ are observed albeit with very low intensities, confirming the homogeneous distribution of the $\mathrm{P}_{2} \mathrm{~W}_{18}$ molecules within the porous structure of MIL-101(Cr). Moreover, the XRD and FT-IR data demonstrate that the structure of the MOF does not destruct during the incorporation of $\mathrm{P}_{2} \mathrm{~W}_{18}$ molecules.

The existence of the Dawson-type polyoxotungstate $\left(\mathrm{P}_{2} \mathrm{~W}_{18}\right)$ in the MIL-101(Cr) framework was further recognized by FT-Raman spectrum of the nanohybrid material in comparison with those of the isolated compounds as shown in Figure 3(a)-(c). It can be seen that the FT-Raman spectrum of the nanohybrid material reveals the typical bands of the porous material MIL-101 and some vibra-

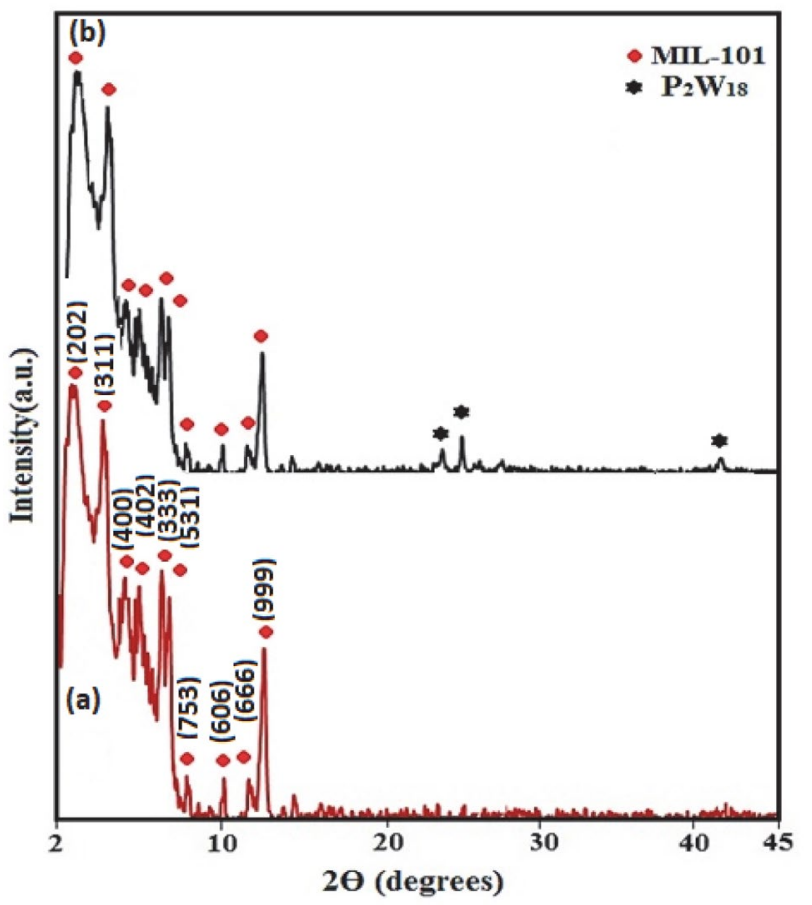

Figure 2. XRD patterns of (a) MIL-101(Cr) and (b) $\mathrm{P}_{2} \mathrm{~W}_{18} @ \mathrm{MIL}-$ $101(\mathrm{Cr})$ samples. 


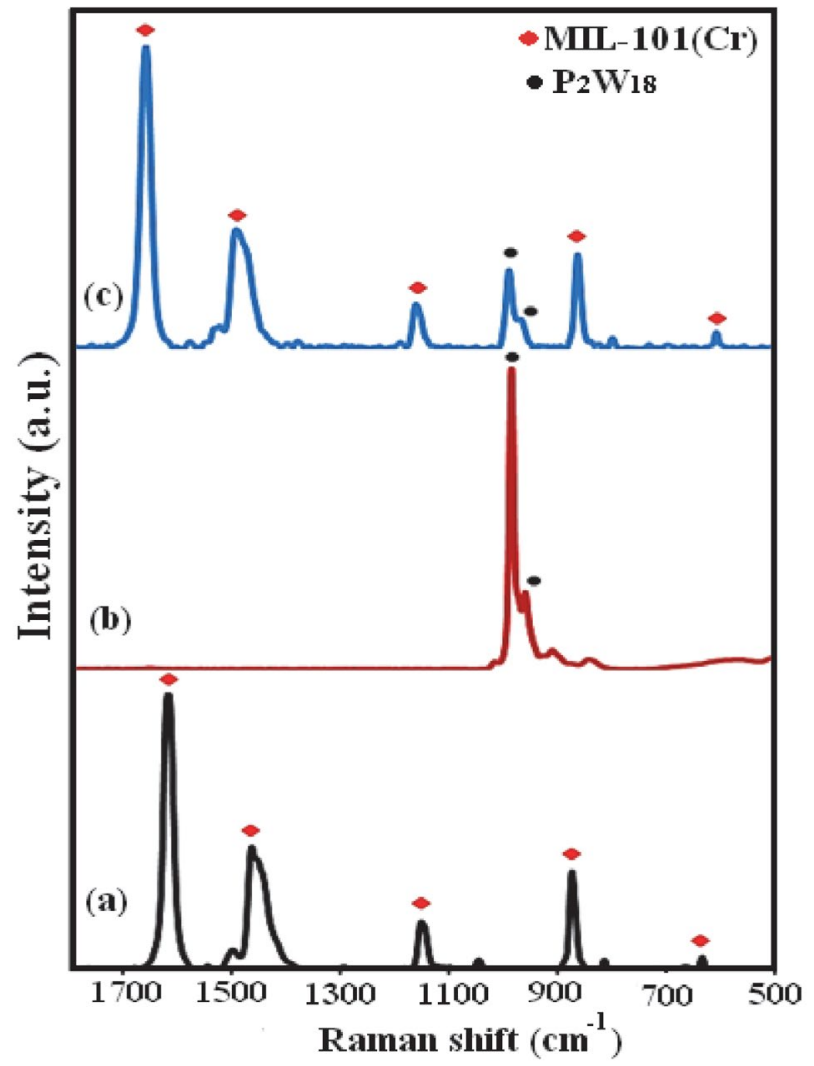

Figure 3. FT-Raman spectra of (a) MIL-101 (Cr), (b) $\mathrm{P}_{2} \mathrm{~W}_{18}$, and (c) $\mathrm{P}_{2} \mathrm{~W}_{18} @$ MIL101 (Cr) samples. tional modes of the $\mathrm{P}_{2} \mathrm{~W}_{18}$. In particular, the strong band located at about $965 \mathrm{~cm}^{-1}$ assigned to $\mathrm{W}=\mathrm{O}$ symmetrical stretching mode is clearly evident in the spectrum of the composite material, $\mathrm{P}_{2} \mathrm{~W}_{18} @ \mathrm{MIL}-101(\mathrm{Cr}){ }^{42}$ The characteristic bands verify the existence of the both $\mathrm{P}_{2} \mathrm{~W}_{18}$ and MIL-101 in the $\mathrm{P}_{2} \mathrm{~W}_{18} @$ MIL-101(Cr) nanocomposite.

The morphology and microstructure of samples were clarified by FE-SEM observations. The SEM images of the samples are indicated in Figure 4. Figure 4(a)-(c) exhibits FE-SEM images of the pristine MIL-101(Cr) particles. It shows that the MIL-101(Cr) particles are irregular polyhedral in shape with high porosity. The sizes of these polyhedral crystals are in the range of $0.5-2 \mu \mathrm{m}$. The SEM images of the $\mathrm{P}_{2} \mathrm{~W}_{18} @ \mathrm{MIL}-101(\mathrm{Cr})$ composite in Figure 4(d)-(f) clearly show that its shape and morphology are similar with those of the MIL-101(Cr). Confirming that the crystalline structure of MIL-101(Cr) remains unchanged after incorporating $\mathrm{P}_{2} \mathrm{~W}_{18}$ anions. However, the porosity of MIL$101(\mathrm{Cr})$ decreased with the incorporation of $\mathrm{P}_{2} \mathrm{~W}_{18}$ anions.

Figure 5 show the EDX spectrum and a representative SEM image of the hybrid nanomaterial with corresponding EDX elemental mappings. The presence of $\mathrm{C}, \mathrm{O}$, $\mathrm{P}, \mathrm{K}, \mathrm{Cr}$, and $\mathrm{W}$ elements in the composite can be proved by the EDX spectrum in Figure 5(a). As presented in Figure 5(b)-(h), the corresponding elemental mapping distribution shows the existence of C, O, P, K, Cr, and W. From the maps, it can be seen that the elements are uniformly distributed over the hybrid nanomaterial, confirming the
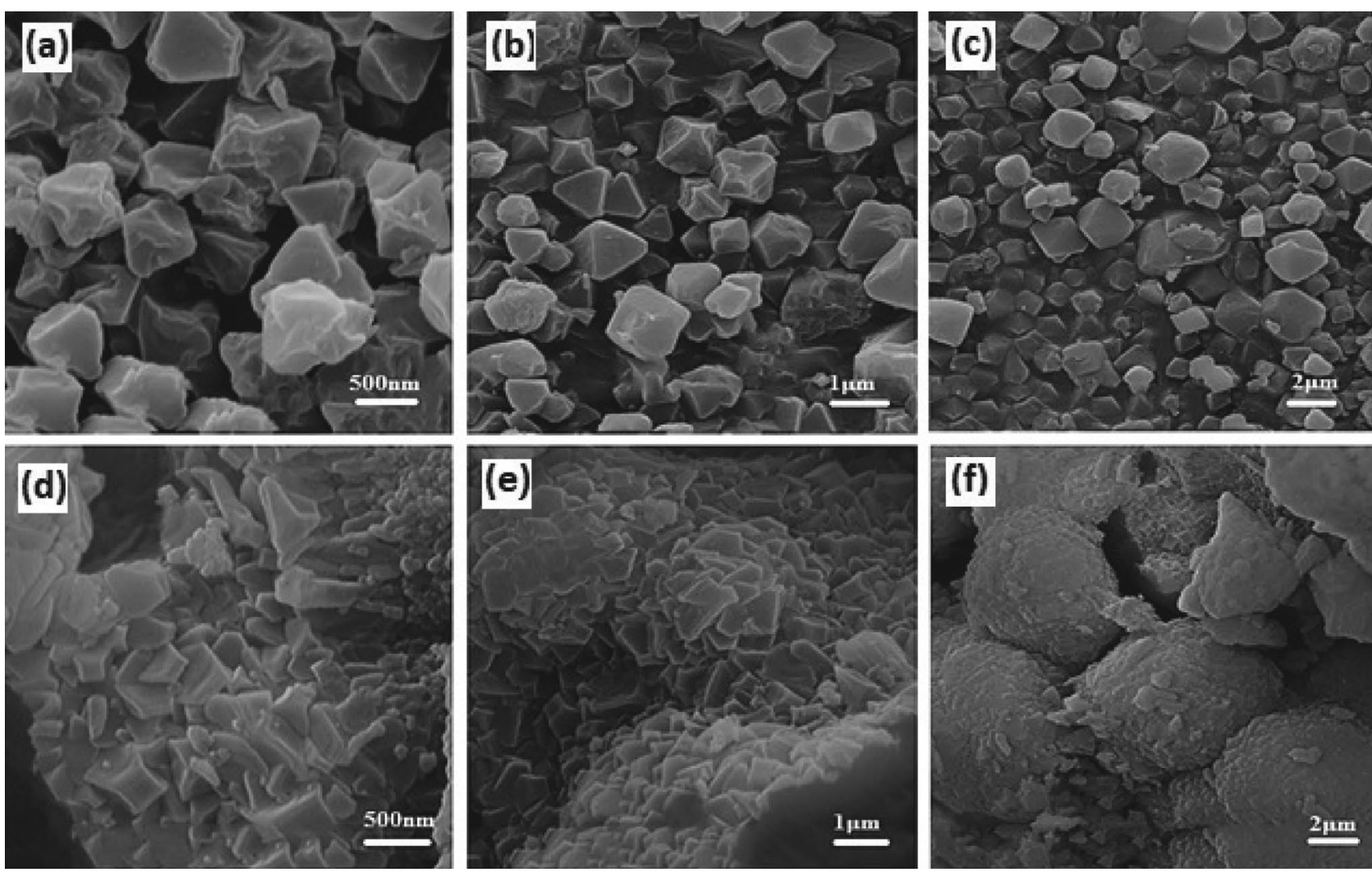

Figure 4. SEM images of (a-c) MIL-101 (Cr) and (d-f) $\mathrm{P}_{2} \mathrm{~W}_{18} @ M I L-10(\mathrm{Cr})$ at different magnifications. 

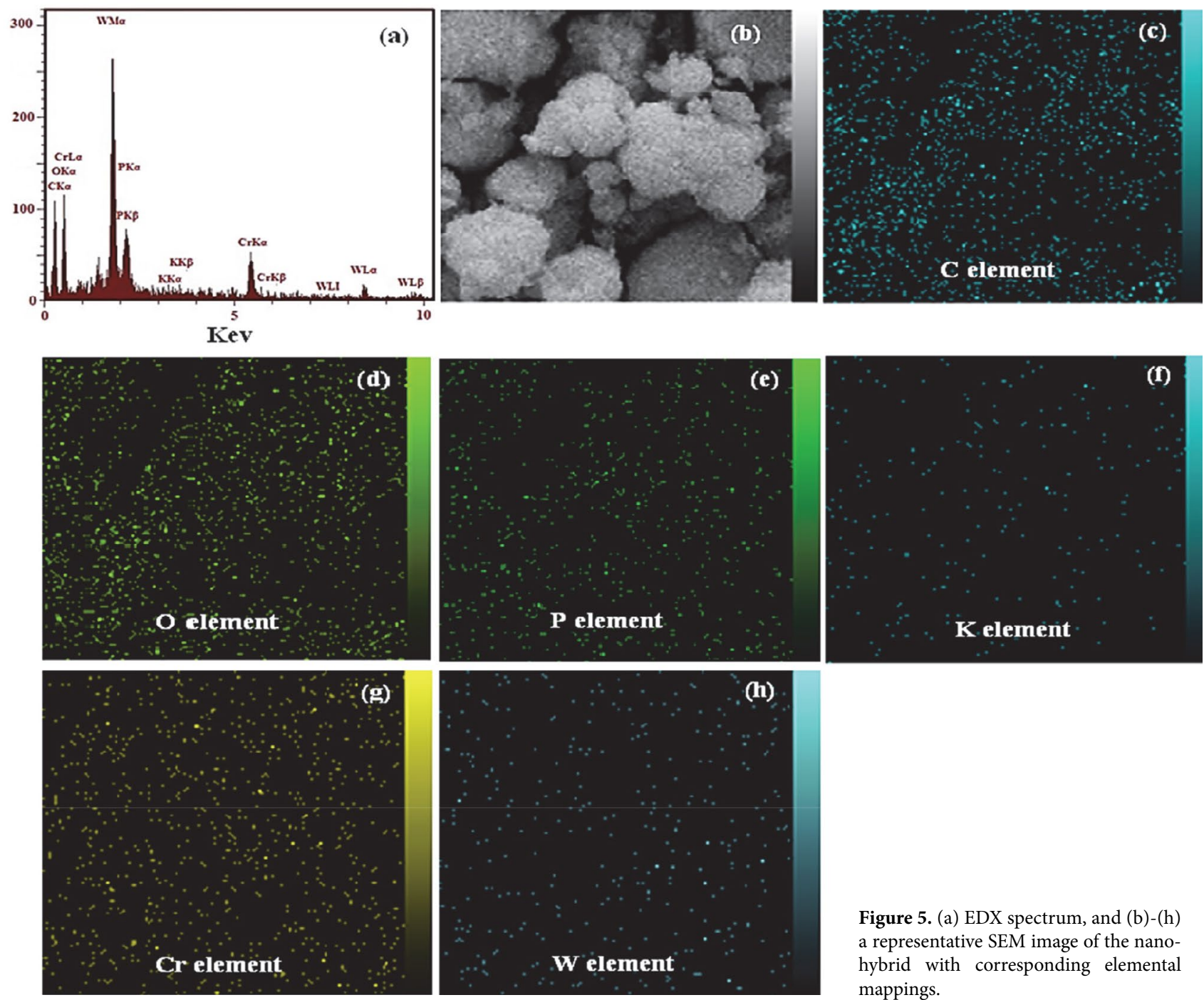

Figure 5. (a) EDX spectrum, and (b)-(h) a representative SEM image of the nanohybrid with corresponding elemental mappings.

homogeneity of the sample. The $\mathrm{K}, \mathrm{P}$ and $\mathrm{W}$ elements were from $\mathrm{P}_{2} \mathrm{~W}_{18}$, thus confirming the uniform incorporation of $\mathrm{P}_{2} \mathrm{~W}_{18}$ anions into the porous MIL-101(Cr) framework.

The BET surface area and pore volume of the samples were determined by $\mathrm{N}_{2}$ adsorption-desorption isotherms at $77 \mathrm{~K}$ and the results are indicated in Figure 6. On the basis of the IUPAC classification, the $\mathrm{N}_{2}$ adsorptiondesorption isotherms of the samples in Figure 6(a) reveal mixed type I/IV isotherms with H4-type hysteresis loop, which is characteristic of solids with mesoporous and microporous cages. ${ }^{36}$ The textural properties of these materials were summarized in Table 1 . Compared with the pris- tine MIL-101, the encapsulated sample demonstrated a significant decrease in surface area, pore volume, and pore diameter owing to the insertion of $\mathrm{P}_{2} \mathrm{~W}_{18}$ polyanion into the cages of the $\mathrm{MOF}^{43}$ The pores of $\mathrm{P}_{2} \mathrm{~W}_{18} @ \mathrm{MIL}-101(\mathrm{Cr})$ were further occupied by the $\mathrm{P}_{2} \mathrm{~W}_{18}$ polyanion which resulted in a further decrease in pore volume and surface area. The Barrett-Joyner-Halenda (BJH) pore size distributions in Fig. 6(b) also confirmed the mesoporous cages of MIL-101 and reflected the volume changes during the encapsulation process. These findings confirm that the $\mathrm{P}_{2} \mathrm{~W}_{18}$ polyanion had been encapsulated within the channels of MIL-101(Cr) rather than outside the surfaces.

Table 1. The textural properties of MIL-101(Cr) and $\mathrm{P}_{2} \mathrm{~W}_{18} @ \mathrm{MIL}-101(\mathrm{Cr})$ samples.

\begin{tabular}{|c|c|c|c|c|c|c|}
\hline Sample & $\begin{array}{l}\text { BET surface } \\
\text { area }\left(\mathrm{m}^{2} / \mathrm{g}\right)\end{array}$ & $\begin{array}{l}\text { Langmuir surface } \\
\text { area }\left(\mathrm{m}^{2} / \mathrm{g}\right)\end{array}$ & $\begin{array}{c}\text { Total pore } \\
\text { volume }\left(\mathrm{cm}^{3} / \mathrm{g}\right)\end{array}$ & $\mathrm{V}_{\text {micro }}$ & $\mathrm{V}_{\text {meso }}$ & $\begin{array}{l}\text { Average pore } \\
\text { diameter (nm) }\end{array}$ \\
\hline MIL-101 Cr & 2692.403 & 3455 & 2.481 & 0.045 & 2.436 & 0.768 \\
\hline $\mathrm{P}_{2} \mathrm{~W}_{18} @ \mathrm{MIL}-101(\mathrm{Cr})$ & 1167.413 & 1671 & 1.108 & 0.029 & 1.079 & 0.504 \\
\hline
\end{tabular}

\footnotetext{
$\mathrm{V}_{\text {micro }}$ : Micropore volume calculated using t-plot method. $\mathrm{V}_{\text {meso }}$ : Mesopore volume calculated using BJH method.
} 

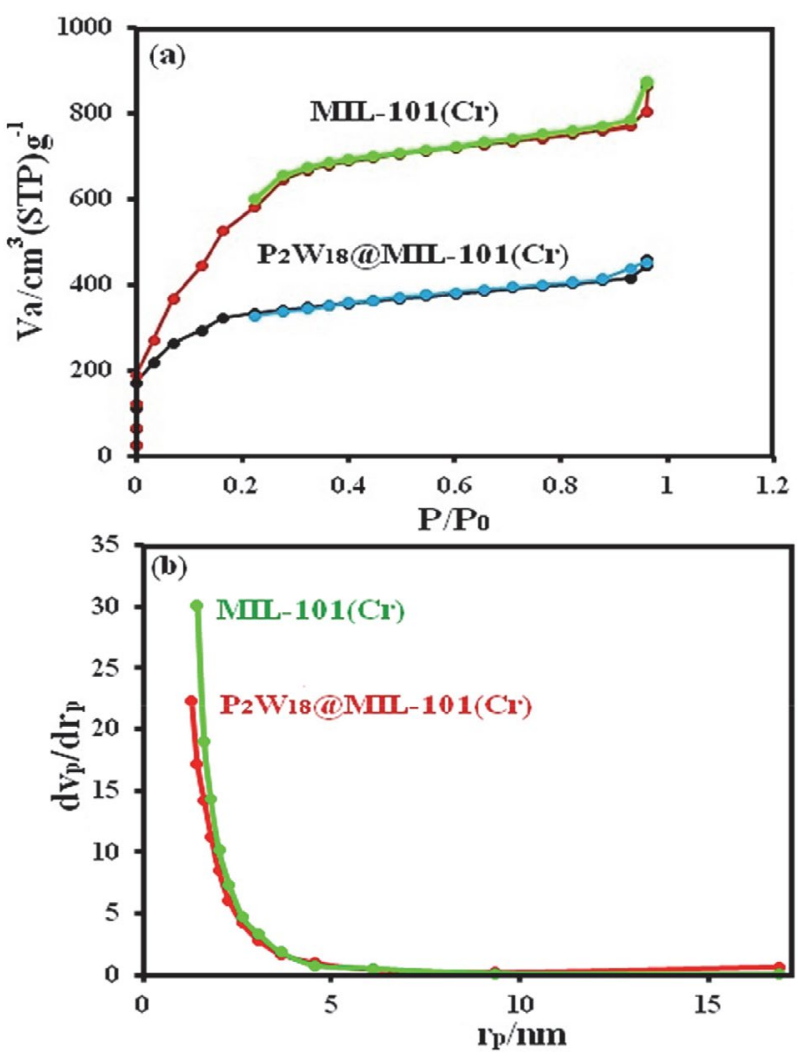

Figure 6. (a) Nitrogen adsorption-desorption isotherms curve at 77 $\mathrm{K}$ and (b) pore size distributions obtained by the $\mathrm{BJH}$ method for nanohybrid.

Zeta potential of materials is another key factor to influence their adsorption capacity, and thus was tested to understand further why $\mathrm{P}_{2} \mathrm{~W}_{18} / \mathrm{MIL}-101(\mathrm{Cr})$ sample can remove cationic dyes $\mathrm{MB}$ and $\mathrm{RhB}$ more effectively than for anionic MO dye. As shown in Figure 7, zeta potential of MIL-101 (Cr) and $\mathrm{P}_{2} \mathrm{~W}_{18} / \mathrm{MIL}-101(\mathrm{Cr})$ samples are about -2.7 and $-12.8 \mathrm{mV}$, respectively. This illustrates that the higher efficiency removal of cationic dye is attributed to the electrostatic attraction interactions between the adsorbents and cationic dye. After modification with $\mathrm{P}_{2} \mathrm{~W}_{18}$, the obtained $\mathrm{P}_{2} \mathrm{~W}_{18}$ /MIL-101 (Cr) showed higher negative zeta potential than that of pristine MIL-101 (Cr), thus capable of adsorbing more cationic dye $\mathrm{MB}$, whereas it is unfavorable for $\mathrm{P}_{2} \mathrm{~W}_{18} / \mathrm{MIL}-101$ (Cr) to adsorb anionic dye MO. The obtained results on the selective adsorption of cationic dyes as well as studies on the Zeta potential of adsorbents clearly suggest that the adsorption of $\mathrm{MB}$ dye on the $\mathrm{P}_{2} \mathrm{~W}_{18} / \mathrm{MIL}-101(\mathrm{Cr})$ nanohybrid has been associated with electrostatic interaction between cationic dye molecules and the highly negative charged $\mathrm{P}_{2} \mathrm{~W}_{18}$ /MIL-101 (Cr) nanohybrid.

\section{2. Adsorption Capability of Nanohybrid Toward Organic Dyes}

In this work, the removal of dyes from contaminated aqueous solutions by using $\mathrm{P}_{2} \mathrm{~W}_{18} @ M I L-101(\mathrm{Cr})$ nanohy-
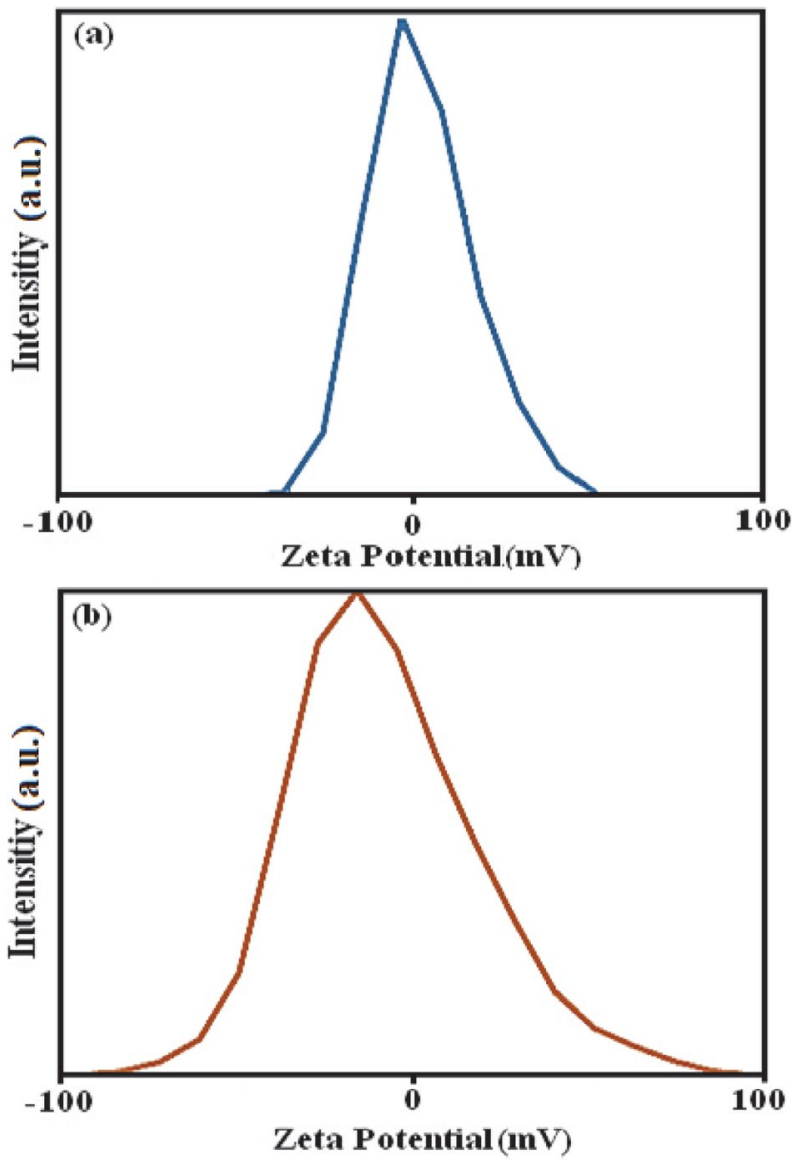

Figure 7. Zeta potential distribution curves of (a) pristine MIL-101 and (b) $\mathrm{P}_{5} \mathrm{~W}_{30} / \mathrm{MIL}-101(\mathrm{Cr})$ hybrid in aqueous solutions.

brid as a novel adsorbent was investigated. Three organic dyes were used herein: $\mathrm{MB}$ and $\mathrm{RhB}$ as cationic dyes and $\mathrm{MO}$ as an anionic dye. From contaminated water, three organic pollutants $(\mathrm{MB}, \mathrm{RhB}$, and $\mathrm{MO}$ ) with different sizes and charges were selected for experiments. The adsorption was monitored using the characteristic absorption peak, which is 664,553 and $463 \mathrm{~nm}$ for $\mathrm{MB}, \mathrm{RhB}$, and MO, respectively. The process of adsorption was specified with the fading of the blue, red and orange colors of $\mathrm{MB}, \mathrm{RhB}$, and $\mathrm{MO}$, respectively. The time dependent UV-Vis absorption spectra of dyes in the presence of $\mathrm{P}_{2} \mathrm{~W}_{18} @ \mathrm{MIL}$ 101(Cr) are shown in Figure 8(a)-(c). As shown in Figure 8(a) and (b), the digital images and UV-Vis spectroscopic results show that the characteristic absorption peaks of cationic MB and RhB dyes at 664 and $553 \mathrm{~nm}$ almost completely disappeared within 0.5 and $2 \mathrm{~min}$, respectively. The result in Figure 8(c) confirms that the nanohybrid is a poor absorbent for anionic $\mathrm{MO}$ dye from aqueous solution even after $30 \mathrm{~min}$.

To further demonstrate the role of anionic $\mathrm{P}_{2} \mathrm{~W}_{18}$ $\mathrm{POM}$ in the composite material, a set of control experiments was designed using pristine MIL-101(Cr) MOF and pure $\mathrm{P}_{2} \mathrm{~W}_{18}$ POM samples as absorbents in removing the different types of organic dyes involving cationic dye $\mathrm{MB}$, 

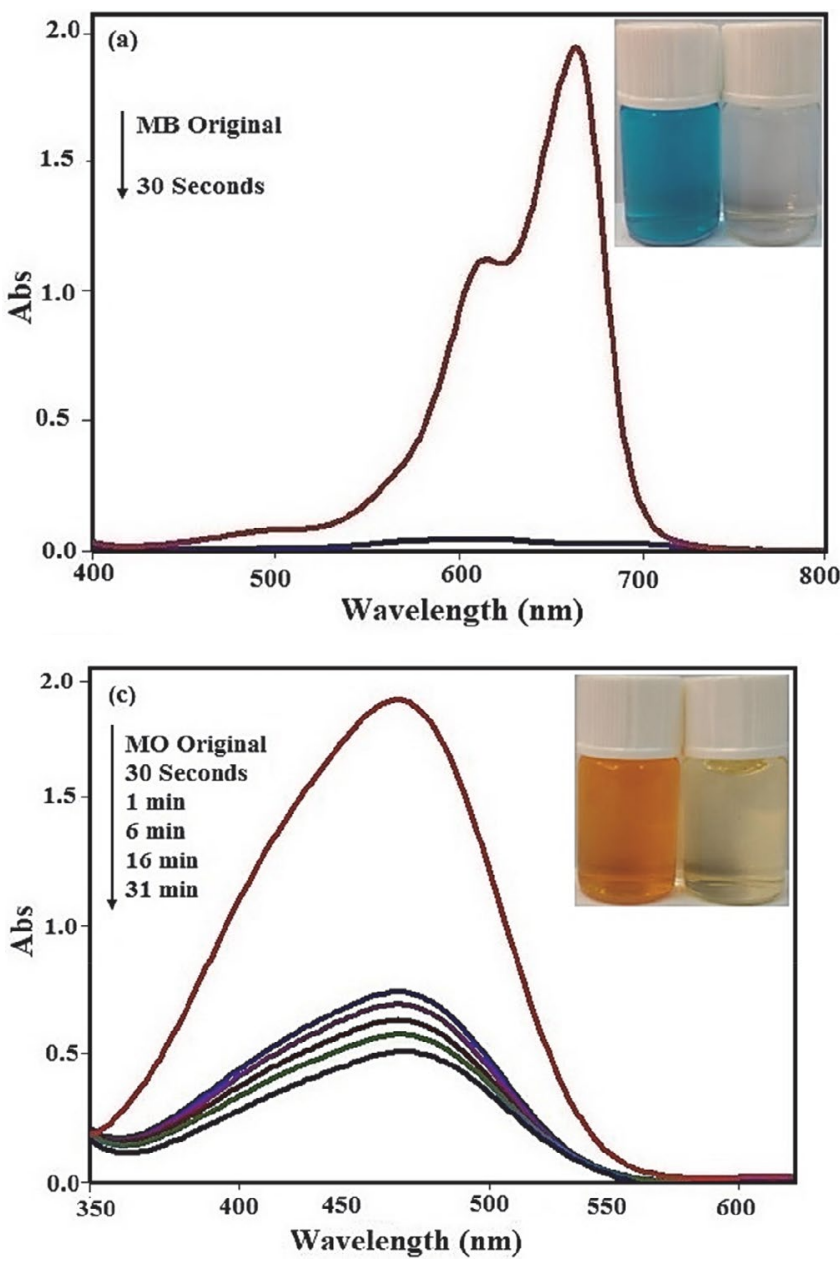

Figure 8. Time dependent UV-Vis spectra during adsorption of dyes over $\mathrm{P}_{2} \mathrm{~W}_{18} @$ MIL-101: (a) MB, (b) RhB, (c) MO. [dye] $]_{0}=25$ $\mathrm{mgL}^{-1} ; 30 \mathrm{~mL}$, adsorbent amount $=30 \mathrm{mg}$, temp. $=25^{\circ} \mathrm{C}$.

$\mathrm{RhB}$ and anionic dye MO. Figure 9 shows the adsorption abilities of Pristine MIL-101(Cr) MOF and pure $\mathrm{P}_{2} \mathrm{~W}_{18}$ $\mathrm{POM}$ samples toward $\mathrm{MB}, \mathrm{RhB}$, and $\mathrm{MO}$ dyes under our reaction conditions. By using Pristine MIL-101(Cr) adsorbent, it is clear from Figure 9(a) and (b) the decrease in intensities of characteristic UV-Vis absorption bands of cationic $\mathrm{MB}$ and $\mathrm{RhB}$ dyes is almost negligible within 60 $\mathrm{min}$, indicating that it has no considerable ability to adsorb cationic dyes even after long contact times whereas it adsorbs completely anionic MO dye within a very short time of 7 min. Figure 9(d)-(f) shows that the pure $\mathrm{P}_{2} \mathrm{~W}_{18}$ sample has different adsorption ability towards the dyes. It can be seen that the intensity of the absorption bands of $\mathrm{MB}$ and $\mathrm{RhB}$ decreases with increasing contact time. The adsorption efficiencies of the pure $\mathrm{P}_{2} \mathrm{~W}_{18}$ sample toward these two dyes are moderate, albeit after long adsorption times of 40-60, (Figure 9(d) and (e)). On the other hand, as can be seen in Figure 9(f), the noticeable decrease in intensity of characteristic absorption band of MO dye was not observed after a long time of $60 \mathrm{~min}$. In Figure 9(g) the adsorption abilities of pure $\mathrm{P}_{2} \mathrm{~W}_{18}$ and pristine MIL101(Cr) and $\mathrm{P}_{2} \mathrm{~W}_{18} @ \mathrm{MIL}-101(\mathrm{Cr})$ samples toward MB,

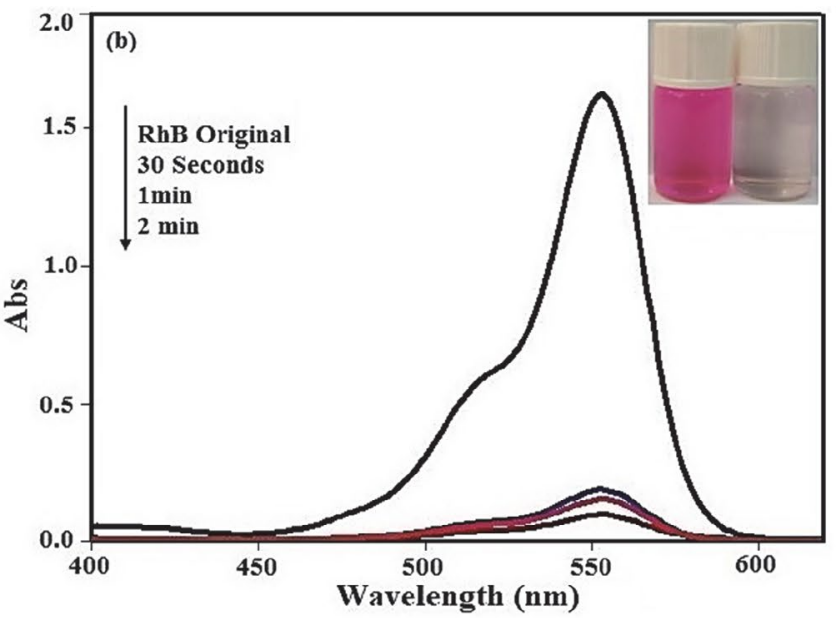

$\mathrm{RhB}$, and MO dyes were compared. The removal percentages of three dyes in the presence of pure $\mathrm{P}_{2} \mathrm{~W}_{18}$ sample as an adsorbent were within $42-66 \%$ in $60 \mathrm{~min}$. The removal rates of pristine MIL-101(Cr) sample for MB and RhB cationic dyes are 28 and $22 \%$ after long adsorption time of 60 min and the removal of MO anionic dye is almost complete $(100 \%)$ in $7 \mathrm{~min}$. It is clear that with respect to recoverability and removal percentages and times, the $\mathrm{P}_{2} \mathrm{~W}_{18} @$ MIL-101(Cr) nanocomposite is more suitable and superior for cationic dyes removal. Thus, pristine MIL-101(Cr) represented superior adsorption capacity for anionic dye $\mathrm{MO}$, whereas the $\mathrm{P}_{2} \mathrm{~W}_{18} @ M I L-101(\mathrm{Cr})$ nanocomposite exhibited high adsorption capacity for cationic dye $\mathrm{MB}$ and $\mathrm{RhB}$. The reason for this phenomenon is that the framework of the pristine MIL-101 is cationic. Amazingly, after the introduction of $\mathrm{P}_{2} \mathrm{~W}_{18}$ polyoxoanions into the cavity of MIL-101, the adsorption capacity of $\mathrm{P}_{2} \mathrm{~W}_{18} @$ MIL-101 has changed a lot comparing with that of the isolated MIL-101 (Figures 8 and 9). This is because that $\mathrm{P}_{2} \mathrm{~W}_{18}$ polyanions encapsulated in MIL-101 MOF can quickly and effectively adsorb $\mathrm{MB}$ and $\mathrm{RhB}$ cationic molecules, whereas strongly reject $\mathrm{MO}$ anions.

\section{2. 1. Effect of $\mathbf{p H}$}

One of the important parameters affecting the adsorption of dyes is the $\mathrm{pH}$ of solution. The effect of $\mathrm{pH}$ on dye elimination by $\mathrm{P}_{2} \mathrm{~W}_{18} @$ MIL-101 (Cr) is shown in Figure 10(a). The results showed that the $\mathrm{pH}$ dependency specifications represent adsorption independent of the entire $\mathrm{pH}$ range because nanohybrids have a high negative charge, which allows them to interact with the positive charges of the dyes in all ranges of pHs.

\section{2. 2. Effect of Initial Dye Concentration}

As shown in Figure 10(b), with an increment in the initial dye concentration, the dye removal decreases. With the increment of the initial $\mathrm{MB}$ concentration in the solution more dye was adsorbed onto $\mathrm{P}_{2} \mathrm{~W}_{18} @$ MIL-101 (Cr), in the event that the dosage of adsorbent remained unchanged. 

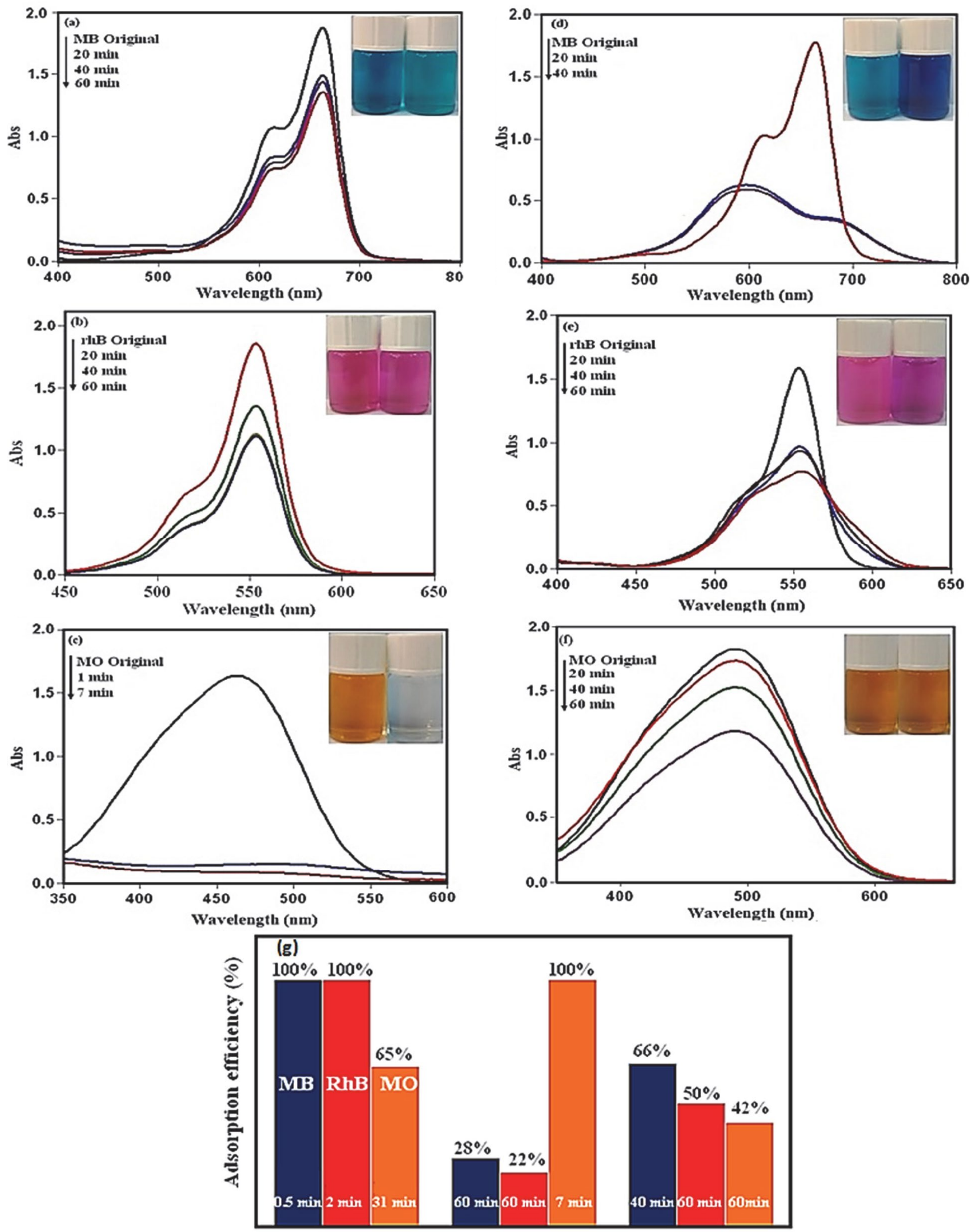

\section{P2IV18@MII-101 (Cr) MII-101 (Cr) Adsorbent}

Figure 9. The adsorption capabilities of (a)-(c) pristine MIL-101(Cr) and (d)-(f) pure $\mathrm{P}_{2} \mathrm{~W}_{18}$ toward MB, RhB, and MO dyes. (g) Adsorption efficiency $(\%)$ of the dyes in the presence of different adsorbent samples. 
The reason for this is that with the increased initial dye concentration, an increment occurs in the driving force of the concentration gradient. The adsorption of dye by $\mathrm{P}_{2} \mathrm{~W}_{18} @$ MIL-101 (Cr) in a low initial concentration is very intense and a balance is reached quickly. In fact, for the initial concentration of $\mathrm{MB}$ in $25 \mathrm{mg} \mathrm{L}^{-1}$, the nanohybrid has a removal efficiency of $100 \%$, in 30 seconds. This demonstrates that $\mathrm{P}_{2} \mathrm{~W}_{18}$ was probably distributed homogeneously and uniformly within the porosities of the MIL-101 (Cr). At a constant adsorbent dosage, with an increasing concentration of the solution, the amount of adsorbed dye increased while the adsorption efficiency of the nanohybrid decreased.

\section{2. 3. Effect of Temperature}

The effect of temperature is another significant physicochemical process parameter because the temperature can change the adsorption capacity of the adsorbent. ${ }^{44}$ The adsorption investigations were carried out at different temperatures $\left(25,35,45,55,65,75,85\right.$ and $95^{\circ} \mathrm{C}$ ) (Figure $10(\mathrm{c}))$. Decreasing the adsorption time with the increase of temperature shows that the adsorption is a spontaneous and endothermic process. With an increase in the temperature, the mobility of the dyes molecules increase and more molecules will be able to penetrate the inner structure of the nanohybrid. ${ }^{45}$

\section{2. 4. Effect of Adsorbent Dosage}

For the purpose of wastewater purification, determining a suitable adsorbent dosage is very important. ${ }^{46}$ The influence of POM@MOF dosage on dye elimination was investigated with fixed conditions such as dye solution volume of $30 \mathrm{~mL}$, dye concentration of $100 \mathrm{mgL}^{-1}, \mathrm{pH}=6$, and temperature of $25{ }^{\circ} \mathrm{C}$ for MB. The adsorbent dosage was applied in different amounts within a range of 10 to 40 $\mathrm{mg}$. Following this, the dye solution was centrifuged and samples were investigated by a spectrophotometer, as Figure 10(d) shows. With increasing adsorbent dosage, the removal of $\mathrm{MB}$ dye increases which could be related to the more adsorption sites. In the result, the suitable adsorbent dosage was found to be $30 \mathrm{mg}$.

To show the advantages of the present adsorbent, we have compared the obtained results in the removal of $\mathrm{MB}$
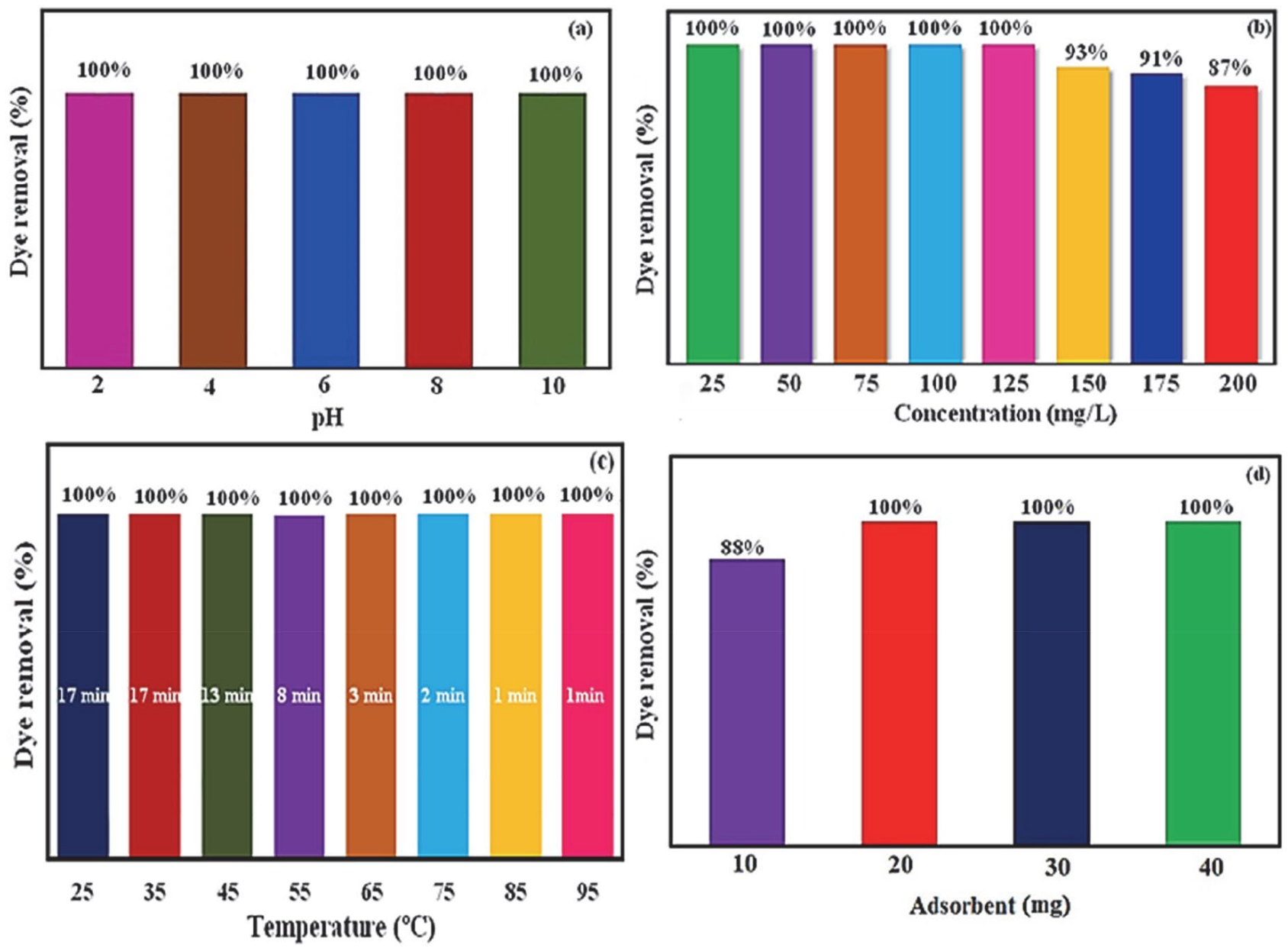

Figure 10. Effects of (a) $\mathrm{pH}$, (b) dye concentration, (c) different temperatures and (d) adsorbent dosage on dyes removel by the $\mathrm{P}_{2} \mathrm{~W}_{18} @ \mathrm{MIL}-101(\mathrm{Cr})$ sample. Conditions: $\mathrm{C}_{0}(\mathrm{MB})=100 \mathrm{mg} / \mathrm{L}$ in $30 \mathrm{~mL}$ dye solution at $25^{\circ} \mathrm{C}$. 
Table 2. Comparison of the results of the newly synthesized nanohybrid with some reported adsorbents for the removal of dye pollutants.

\begin{tabular}{|c|c|c|c|c|c|}
\hline Adsorbent & Dye pollutant & $\begin{array}{c}\text { Concentration } \\
\text { of dye }(\mathrm{mg} / \mathrm{L})\end{array}$ & $\begin{array}{c}\text { Removal efficiency } \\
(\%)\end{array}$ & $\begin{array}{l}\text { Time } \\
(\min )\end{array}$ & Ref \\
\hline $\mathrm{H}_{6} \mathrm{P}_{2} \mathrm{~W}_{18} \mathrm{O}_{62} @ \mathrm{Cu}_{3}(\mathrm{BTC})_{2}$ & $\mathrm{MB}$ & 20 & 80 & 60 & {$[12]$} \\
\hline $\mathrm{PV}_{2} \mathrm{Mo}_{10} / \mathrm{M}$ (membrane) & $\mathrm{MB}$ & 20 & 100 & $48 \mathrm{~h}$ & {$[47]$} \\
\hline $\mathrm{H}_{3} \mathrm{PW}_{12} \mathrm{O}_{40} / \mathrm{ZIF}-8$ & $\mathrm{MB}$ & 60 & 100 & 30 & {$[48]$} \\
\hline $\mathrm{LaMnO}_{3} @ \mathrm{SiO}_{2} / \mathrm{PW}_{12}$ & $\mathrm{MB}$ & 25 & 98 & 30 & {$[49]$} \\
\hline PW 11 V@ MIL-101(Cr) & $\mathrm{MB}$ & 10 & 98 & 60 & {$[26]$} \\
\hline PW 11 V@ MIL-101(Cr) & RhB & 10 & 60 & 60 & {$[26]$} \\
\hline MoS $@$ @MIL-101 (Cr) & RhB & 20 & 90 & 10 & {$[52]$} \\
\hline $\mathrm{Fe}_{3} \mathrm{O}_{4} /$ reduced graphene oxide & $\mathrm{RhB}$ & 5 & 91 & 120 & {$[50]$} \\
\hline PW ${ }_{12} @ M I L-101(\mathrm{Fe})$ & $\mathrm{MB}$ & 100 & 100 & 30 & {$[37]$} \\
\hline $\mathrm{Fe}_{3} \mathrm{O}_{4} / \mathrm{MIL}-101(\mathrm{Cr})$ & $\mathrm{MO}$ & 25 & 25 & 150 & {$[51]$} \\
\hline $\mathrm{P}_{2} \mathrm{~W}_{18} @ \mathrm{MIL}-101$ (Cr) & $\mathrm{MB}$ & 25 & 100 & 0.5 & This work \\
\hline $\mathrm{P}_{2} \mathrm{~W}_{18} @ \mathrm{MIL}-101$ (Cr) & RhB & 25 & 100 & 2 & This work \\
\hline $\mathrm{P}_{2} \mathrm{~W}_{18} @ \mathrm{MIL}-101$ (Cr) & $\mathrm{MO}$ & 25 & 31 & 73 & This work \\
\hline
\end{tabular}
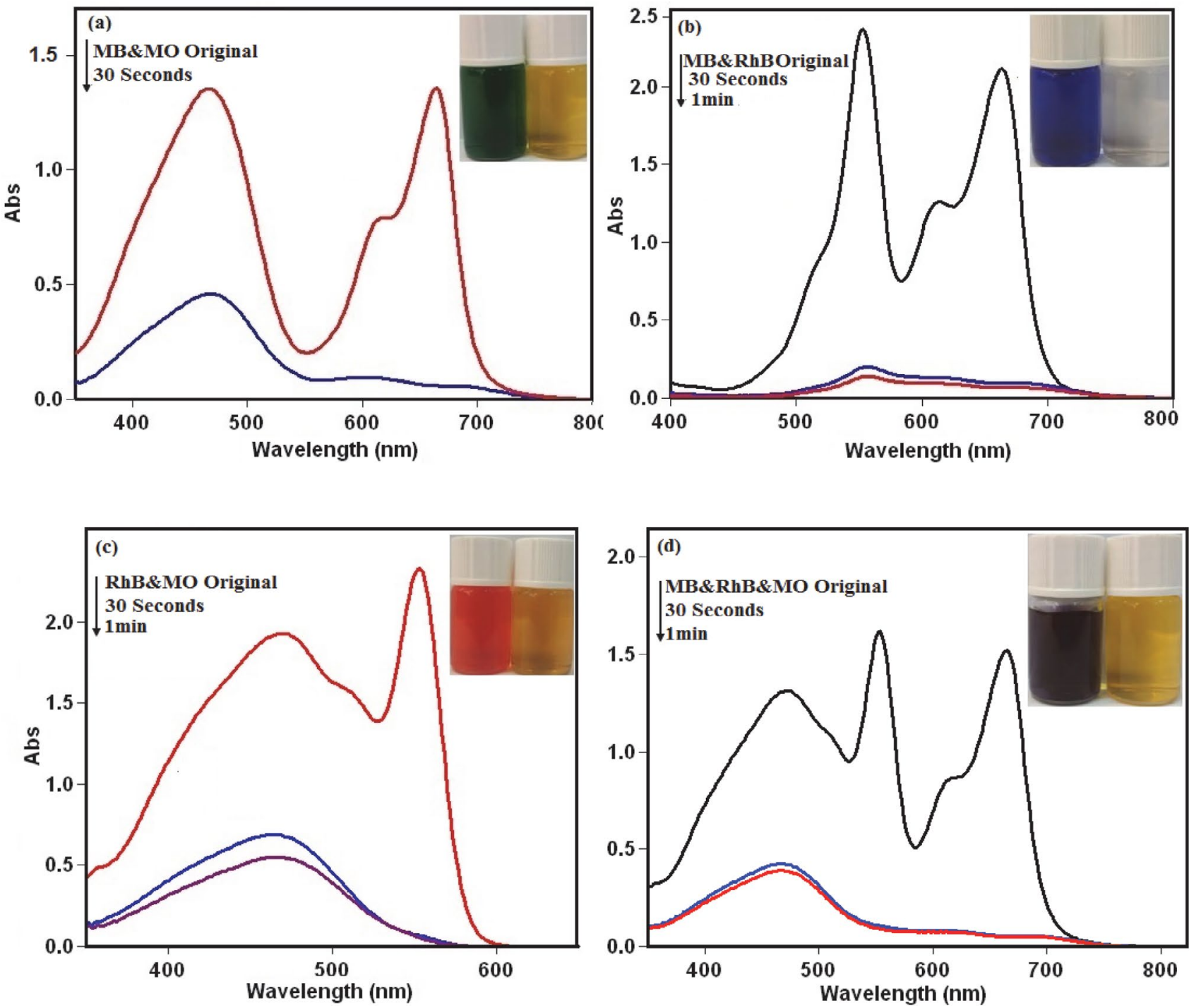

Figure 11. The selective adsorption ability of $\mathrm{P}_{2} \mathrm{~W}_{18} @ M I L-101$ (Cr) toward the mixed dyes of (a) MB/MO, (b) MB/RhB, (c) RhB/MO and (d) MB/ $\mathrm{MO} / \mathrm{RhB}$. Conditions: $\mathrm{C}_{0}(\mathrm{MB})=\mathrm{C}_{0}(\mathrm{RhB})=\mathrm{C}_{0}(\mathrm{MO})=25 \mathrm{mg} / \mathrm{L}$; adsorbent dose $=25 \mathrm{mg}$ in $30 \mathrm{~mL}$ mixed dye solution at $25^{\circ} \mathrm{C}$. 
from aqueous solution by the $\mathrm{P}_{2} \mathrm{~W}_{18} @ \mathrm{MIL}-101(\mathrm{Cr})$ nanohybrid with some reported similar adsorbents in the literature. ${ }^{12,20,37,47-52}$ From Table 2, it is clear that with respect to the adsorption conditions (adsorption time, initial dye concentration and adsorption efficiency), the present method is more suitable and/or superior. We can see that the adsorption process in the presence of most reported adsorbents required longer reaction time compared to the $\mathrm{P}_{2} \mathrm{~W}_{18} @ \mathrm{MIL}-101(\mathrm{Cr})$ nanohybrid. The $\mathrm{P}_{2} \mathrm{~W}_{18}$ polyanions with a large number of negative charges incorporated in the hybrid have a stronger attraction force with the positive charges of cationic dyes (e.g. MB). In fact, higher adsorption efficiency of the $\mathrm{P}_{2} \mathrm{~W}_{18} @ \mathrm{MIL}-101(\mathrm{Cr})$ is due to synergistic effect between MIL-101(Cr) and $\mathrm{P}_{2} \mathrm{~W}_{18}$ polyanions.

\section{2. 5. Selective Adsorption Ability of the Nanohybrid for the Mixed Organic Dyes}

The selective adsorption of dyes from their mixture is more attractive and challenging. To verify the selective adsorption property of the $\mathrm{P}_{2} \mathrm{~W}_{18} @ \mathrm{MIL}-101(\mathrm{Cr})$ nanohybrid adsorbent, the dye molecules with different sizes and charges were selected for the experiments, considering that the charge and size of organic dyes are the two major factors controlling the adsorption process. In this work, cationic MB (molecule size $1.38 \mathrm{~nm} \times 0.64 \mathrm{~nm} \times 0.21 \mathrm{~nm}$ ), cationic $\mathrm{RhB}$ (molecule size $1.56 \mathrm{~nm} \times 1.35 \mathrm{~nm} \times 0.42 \mathrm{~nm}$ ) and anionic MO (molecule size $1.54 \mathrm{~nm} \times 0.48 \mathrm{~nm} \times 0.28 \mathrm{~nm}$ ) were selected, considering that they possess different sizes and different charges. As shown in Figure 10(a)-(c), the selective uptake of dyes was tested using the $\mathrm{MB} / \mathrm{MO}$ mixture $\left(30 \mathrm{~mL}, \mathrm{C}_{0 \mathrm{MB}}=\mathrm{C}_{0 \mathrm{MO}}=25 \mathrm{mg} / \mathrm{L}\right), \mathrm{MB} / \mathrm{RhB}$ mixture $(30$ $\left.\mathrm{mL}, \mathrm{C}_{0 \mathrm{MB}}=\mathrm{C}_{0 \mathrm{RhB}}=25 \mathrm{mg} / \mathrm{L}\right)$ and $\mathrm{MO} / \mathrm{RhB}$ mixture $(30$ $\mathrm{mL}, \mathrm{C}_{0 \mathrm{MO}}=\mathrm{C}_{0 \mathrm{RhB}}=25 \mathrm{mg} / \mathrm{L}$ ) with $25 \mathrm{mg}$ of the $\mathrm{P}_{2} \mathrm{~W}_{18} @$ MIL-101(Cr) absorbent, and then the process was monitored by UV-vis spectroscopy. As $\mathrm{MB}$ and $\mathrm{MO}$ are similar in molecule size, the preferable uptake of $\mathrm{MB}$ from $\mathrm{MB} /$ MO mixture may be assigned to the anionic nature of $\mathrm{P}_{2} \mathrm{~W}_{18} @ \mathrm{MIL}-101(\mathrm{Cr})$, as shown in Figure 11(a). For comparison, cationic RhB was selected to mix with cationic $\mathrm{MB}$, and the results revealed that $\mathrm{MB}$ was also preferably adsorbed on $\mathrm{P}_{2} \mathrm{~W}_{18} @ \mathrm{MIL}-101(\mathrm{Cr})$ from the $\mathrm{MB} / \mathrm{RhB}$ mixture as illustrated in Figure 11(b), which may imply that the uptake of dyes is heavily influenced by molecule size along with charges. Also, for the binary $\mathrm{MO} / \mathrm{RhB}$ mixture, cationic $\mathrm{RhB}$ dye was preferably adsorbed (Figure 11(c)). It can be anticipated that the composite material may also have an outstanding adsorption and separation behavior in treatment of a ternary mixture of MB, RhB and MO. As exhibited in Figure 11(d), the representative peaks of $\mathrm{MB}$ and $\mathrm{RhB}$ all disappeared quickly in mixed dye, only the characteristic absorption peaks of $\mathrm{MO}$ left, suggesting that the $\mathrm{P}_{2} \mathrm{~W}_{18} @$ MIL-101(Cr) could selectively capture cationic dyes when is utilized in the corresponding ternary mixture.

\section{2. 6. Adsorption Kinetics}

According to the adsorption kinetics, several models for a mechanism of solution adsorption onto an adsorbent can be expressed. To investigate the controlling mechanisms and the rate controlling steps in the overall adsorption process, such as diffusion control, chemical reaction, and mass transfer, different kinetic models (intraparticle diffusion, pseudo-first-order, and pseudo-second-order) are utilized. To study the empirical data and investigate the probability of intraparticle diffusion that can influence the adsorption process, the equation below is used: ${ }^{53}$

$$
q_{t}=k_{p} t^{\frac{1}{2}}+I
$$

The values I and $\mathrm{kp}$ demonstrate the intraparticle dissemination rate constant and intercept, respectively. The parameters I, $\mathrm{kp}$ and $\mathrm{R}^{2}$ were computed for several dye concentrations and listed in Table 4. The parameter I indicates the thickness of the frontier layer. The results show that the surface adsorption can be performed by the dissemination of the particles. Generally, a pseudo-first-order equation is illustrated as follows: ${ }^{54}$

$$
\log \left(q_{e}-q_{t}\right)=\log \left(q_{e}\right)-\left(\frac{k_{1}}{2.303}\right) t
$$

The parameters qe and $\mathrm{k}_{1}$ indicate the value of dye adsorbed at equilibrium $(\mathrm{mg} / \mathrm{g})$ and the equilibrium rate constant of the pseudo-first-order kinetic $(1 / \mathrm{min})$, respectively.

The pseudo-second-order kinetic equation is expressed as follows: ${ }^{55,56}$

$$
\frac{t}{q_{t}}=\frac{1}{k_{2} q_{e}{ }^{2}}+\left(\frac{1}{q_{e}}\right) t
$$

\begin{tabular}{|c|c|c|c|c|c|c|c|c|c|c|}
\hline \multirow[t]{2}{*}{$\begin{array}{l}\mathrm{C}_{0} \\
(\mathrm{mg} / \mathrm{L})\end{array}$} & \multirow[t]{2}{*}{$\begin{array}{c}\mathbf{q e}_{\exp } \\
(\mathbf{m g} / \mathrm{g})\end{array}$} & \multicolumn{2}{|c|}{$\begin{array}{c}\text { Pseudo-first-order } \\
\text { kinetic }\end{array}$} & \multicolumn{4}{|c|}{$\begin{array}{l}\text { Pseudo-second-order } \\
\text { kinetic }\end{array}$} & \multicolumn{3}{|c|}{$\begin{array}{c}\text { Intraparticle diffusion } \\
\text { model }\end{array}$} \\
\hline & & $\begin{array}{c}\mathrm{k}_{1} \\
\left(\mathrm{~min}^{-1}\right)\end{array}$ & $\begin{array}{c}\mathrm{qe}_{\mathrm{cal}} \\
(\mathrm{mg} / \mathrm{g})\end{array}$ & $\mathrm{R}_{1}{ }^{2}$ & $\begin{array}{c}\mathrm{k}_{2} \\
(\mathrm{~g} / \mathrm{mg} \mathrm{min})\end{array}$ & $\underset{(\mathrm{mg} / \mathrm{g})}{\mathbf{q e}_{\mathrm{cal}}}$ & $\mathbf{R}_{2}^{2}$ & kp & I & $\mathbf{R}_{3}{ }^{2}$ \\
\hline 150 & 146.1 & 0.07 & 7.4 & 0.9892 & 0.003 & 151.5 & 0.9992 & 12.1 & 66.7 & 0.6937 \\
\hline 175 & 169.47 & 0.07 & 12.2 & 0.9891 & 0.003 & 175.4 & 0.9993 & 13.8 & 59.8 & 0.6819 \\
\hline 200 & 192 & 0.04 & 18.1 & 0.9849 & 0.002 & 200 & 0.9989 & 15.8 & 50.9 & 0.6937 \\
\hline
\end{tabular}

Table 3. Kinetic models parameters for MB dye adsorption at 150, 175 and $200 \mathrm{mg} / \mathrm{L}$ dye concentrations. 

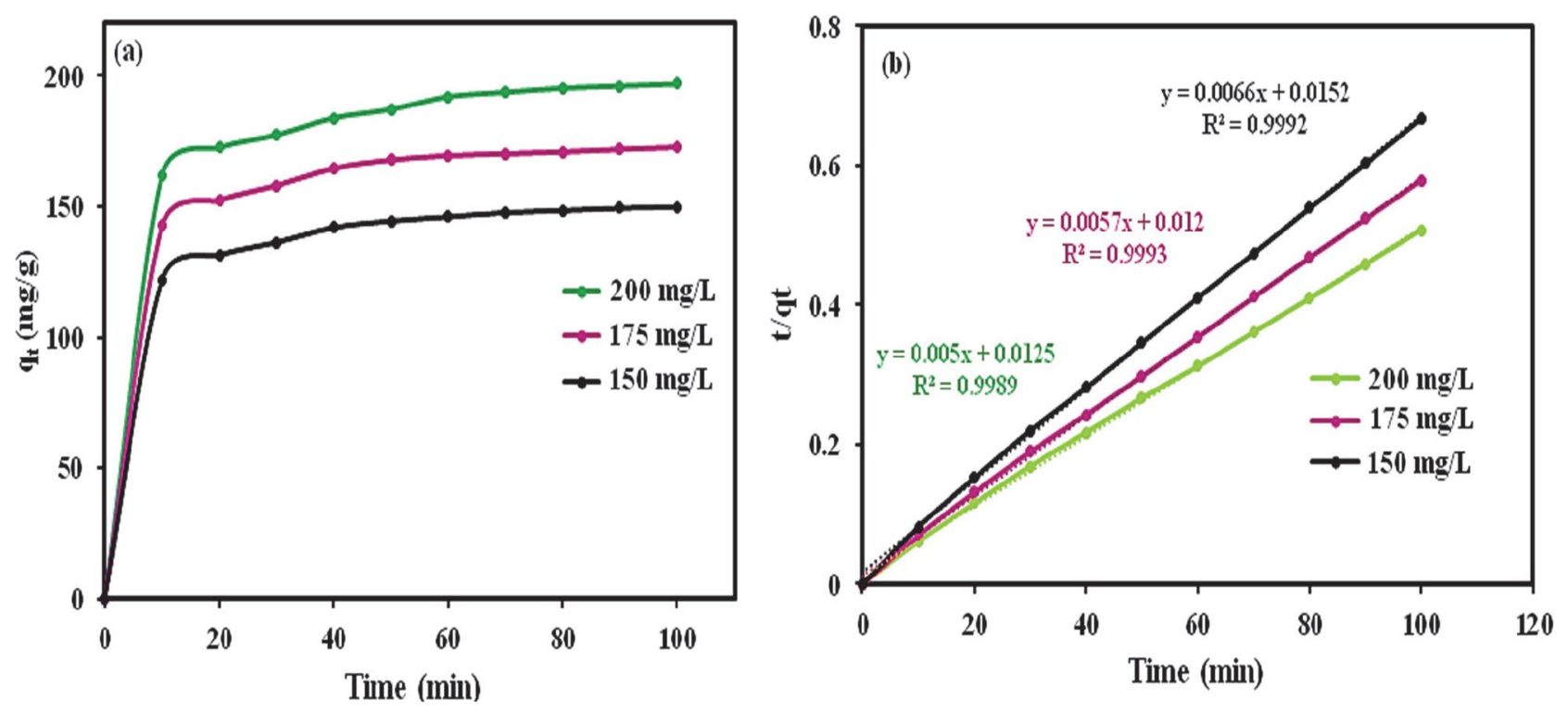

Figure 12. Kinetic adsorption data plots for MB: (a) plot of removal rate qt vs. $t$ and (b) pseudo-second- order adsorption kinetics on nanomaterial.

To adsorb dyes onto $\mathrm{P}_{2} \mathrm{~W}_{18} @ \mathrm{MIL}-101(\mathrm{Cr})$ at the different dye concentration amounts $(150,175$, and 200 $\mathrm{mg} / \mathrm{L}$ ) linear plots of $\mathrm{t} / \mathrm{qt}$ versus $\mathrm{t}$ are indicated in Figure 12. The parameters of $K_{1}, K_{2}, R_{1}{ }^{2}$ (correlation coefficient for pseudo-first-order adsorption kinetics), $\mathrm{R}_{2}^{2}$ (correlation coefficient for pseudo-second-order adsorption kinetics) $\mathrm{K}_{\mathrm{p}} \mathrm{I}$, and $\mathrm{R}_{3}{ }^{2}$ (correlation coefficient for intra-particle diffusion model) were calculated and have been presented in Table 3. As it can be seen in Table 3, the values of the $\left.\mathrm{q}_{\mathrm{e}(\exp )}\right)(\mathrm{mg} / \mathrm{g})$ are lower than the calculated $\mathrm{q}_{\mathrm{e}(\mathrm{cal})}$ $(\mathrm{mg} / \mathrm{g})$ according to pseudo-second-order equation, which further supports that the pseudo-second-order equation can be utilized to describe the adsorption of dye onto the $\mathrm{P}_{2} \mathrm{~W}_{18} @ \mathrm{MIL}-101$ (Cr).

\section{2. 7 Adsorption Isotherm}

The design of an adsorption system for an adsorbent provides the most suitable correlation for the equilibrium curves. Different adsorption isotherms were investigated such as the Freundlich, Langmuir, and Temkin isotherms. The basic supposition in the Langmuir theory is that the adsorption in the adsorbent sample occurs at particular homogeneous sites. This equation can be expressed linearly as bellow: ${ }^{57}$

$$
\frac{C_{e}}{q_{e}}=\frac{1}{K_{L} Q_{m}}+\frac{C_{e}}{Q_{m}}
$$

The parameters $\mathrm{C}_{\mathrm{e}}, \mathrm{K}_{\mathrm{L}}$, and $\mathrm{q}_{\mathrm{m}}$ are the equilibrium concentration of the dye solution $(\mathrm{mg} / \mathrm{L})$, the Langmuir constant $(\mathrm{L} / \mathrm{mg})$, and the maximum adsorption capacity $(\mathrm{mg} / \mathrm{g})$, respectively.

By assuming a non-homogenous surface with a non-uniform diffusion of heat of adsorption over the surface the Freundlich equation is derivative. The Freundlich equation can be represented linearly as follows: ${ }^{58}$

$$
\log q_{e}=\log K_{F}+\left(\frac{1}{n}\right) \log C_{e}
$$

Where $\mathrm{KF}$ and $1 / \mathrm{n}$ indicate the adsorption capacity at unit concentration and the adsorption severity as Freundlich constants, respectively. The isotherm type is determined according to the values of $1 / \mathrm{n}$, that is, unfavorable $(1 / \mathrm{n}>1)$, favorable $(0<1 / \mathrm{n}<1)$, and irreversible $(1 / \mathrm{n}=$ 0). ${ }^{59}$ Some indirect adsorbate/adsorbate interactions studied by Temkin in relation to adsorption isotherms were examined, and it was suggested that for all the molecules, the heat of adsorption increases linearly with coverage. The Temkin equation can be expressed linearly as follows: ${ }^{60}$

$$
q_{e}=B_{1} \operatorname{LnK}_{T}+B_{1} \operatorname{Ln} C_{e} \rightarrow B_{1}=\frac{R T}{b}
$$

The Temkin isotherm expresses that pending some maximum binding energy, the adsorption is characterized by a uniform distribution of binding energies. The isotherm constants $B_{1}$ and $K_{T}$ were determined using the values qe and Ln Ce, which represent the slope and the intercept, respectively. The constant $B_{1}$ represents the heat of adsorption and the constant $\mathrm{K}_{\mathrm{T}}$ indicates the maximum binding energy. The correlation coefficients for the Langmuir, Freundlich and Temkin isotherms were obtained from Figures 13(a)-(b) are listed in Table 4. Based on the results obtained, the Langmuir isotherm is most suitable for studying $\mathrm{MB}$ dye.

\section{2. 8. Adsorption Thermodynamics}

In the adsorption process, energy and entropy are very significant. The value of $\mathrm{MB}$ adsorbed at equilibrium 
Table 4. Isotherm constants for MB dye adsorption at 150, 175 and $200 \mathrm{mg} / \mathrm{L}$ dye concentrations

\begin{tabular}{|c|c|c|c|c|c|c|c|c|c|}
\hline \multirow[t]{2}{*}{ Dye } & \multicolumn{3}{|c|}{ Langmuir isotherm model } & \multicolumn{3}{|c|}{ Freundlich isotherm model } & \multicolumn{3}{|c|}{ Temkin isotherm model } \\
\hline & $\mathrm{R}^{2}$ & $\mathrm{~K}_{\mathrm{L}}\left(\mathrm{L} \mathrm{mg}^{-1}\right)$ & $\mathrm{Qm}\left(\mathrm{mg} \mathrm{g}^{-1}\right)$ & $\mathrm{R}^{2}$ & $\mathrm{~K}_{\mathrm{F}}\left(\mathrm{mg} \mathrm{g}^{-1}\right)$ & $\mathrm{n}\left(\mathrm{mgL}^{-1}\right)$ & $\mathrm{R}^{2}$ & $\mathrm{~K}_{\mathrm{T}}$ & $\mathrm{B}_{1}$ \\
\hline MB & 1 & 0.3 & 270 & 0.9944 & 7 & 2.6 & 0.9987 & 2.6 & 63.83 \\
\hline
\end{tabular}
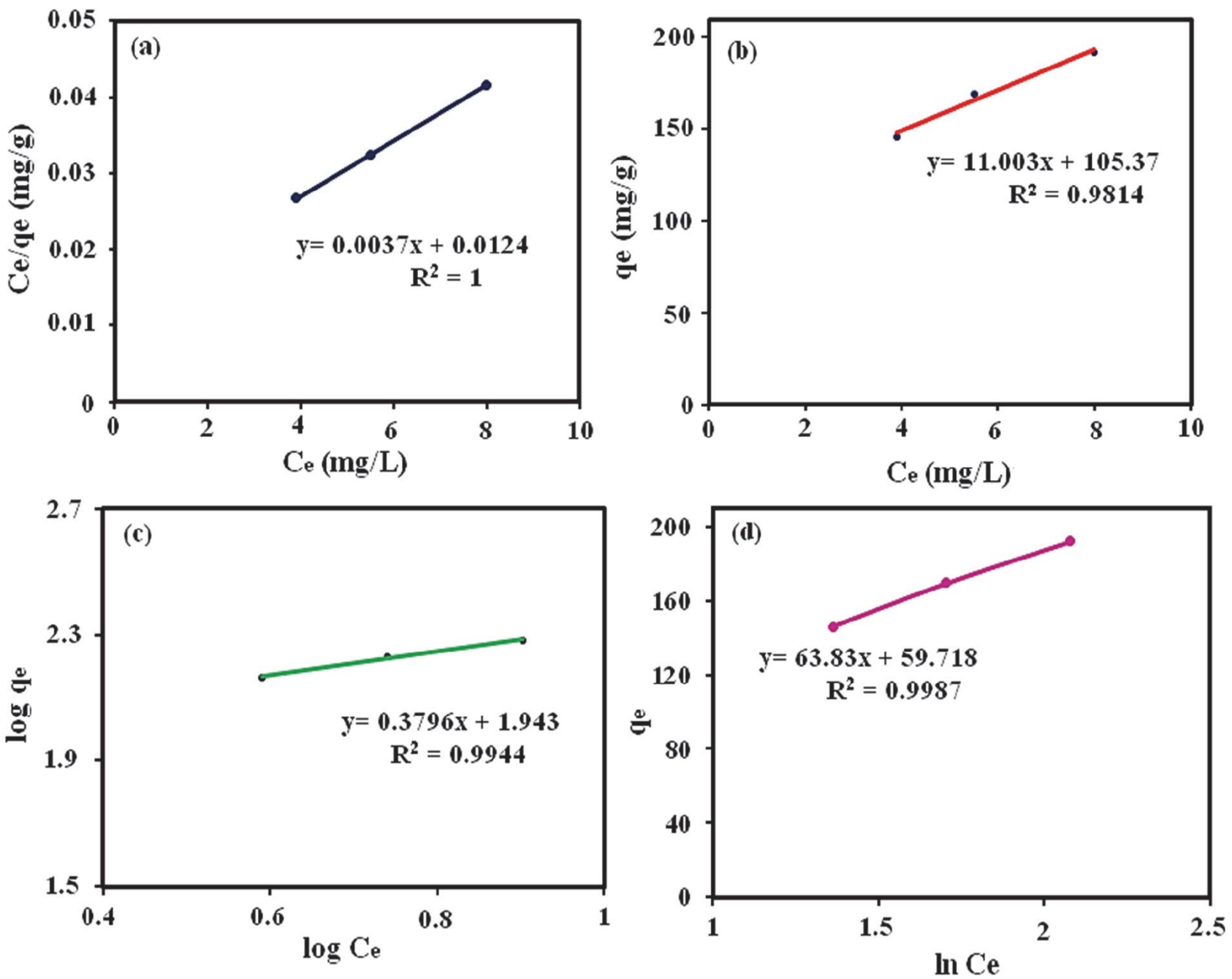

Figure 13. (a) Isotherm plot of dye elimination, (b) Langmuir isotherm, (c) Freundlich isotherm, (d) Temkin isotherm of dye removal by $\mathrm{P}_{2} \mathrm{~W}_{18} @$ MIL-101 (Cr).

for determining the thermodynamic parameters at the different temperatures was examined. The enthalpy $\left(\Delta \mathrm{H}^{\circ}: \mathrm{kJ} /\right.$ $\mathrm{mol})$, entropy $\left(\Delta \mathrm{S}^{\circ}: \mathrm{kJ} / \mathrm{mol} \mathrm{K}\right)$, and change in Gibbs energy $\left(\Delta \mathrm{G}^{\mathrm{o}}: \mathrm{kJ} / \mathrm{mol}\right)$ were obtained using the following equations: ${ }^{61}$

$$
\begin{aligned}
& \ln K_{C}=\left(\frac{\Delta S^{0}}{R}\right)-\left(\frac{\Delta H^{0}}{R T}\right) \\
& \Delta G^{0}=\Delta H^{0}-T \Delta S^{0}
\end{aligned}
$$

The parameters $\mathrm{Kc}(\mathrm{L} / \mathrm{g}), \mathrm{T}$, and $\mathrm{R}(8.314 \mathrm{~J} / \mathrm{mol} \mathrm{K})$ are the standard thermodynamic equilibrium constant, the equilibrium concentration of the dye in the solution (Ce), the value of dye adsorbed on the adsorbent of the solution at equilibrium (qe), the absolute temperature, and the gas constant, respectively. The values $\Delta \mathrm{H}^{\circ}$ and $\Delta \mathrm{S}^{\circ}$ can be determined by drawing curves of $\ln$ Kc versus $1 / \mathrm{T}$ from the slopes and intercepts, respectively (Figure 14). Table 5 indicates the negative values of $\Delta \mathrm{G}^{\circ}$ and positive $\Delta \mathrm{H}^{\circ}$. The data demonstrate that the $\mathrm{MB}$ adsorption process is an endothermic and spontaneous process. The increase randomly at the solid/solution interface based on the positive amount of $\Delta S^{\circ}$ occurs in the internal structure of the adsorption of $\mathrm{MB}$ dye onto $\mathrm{P}_{2} \mathrm{~W}_{18} @ \mathrm{MIL}-101$ (Cr). Also, the positive amount of $\Delta \mathrm{H}^{\circ}$ indicates the presence of an ener- 
gy impediment in the adsorption process and the endothermic process. ${ }^{62,63}$

According to the negative amounts of $\Delta \mathrm{G}^{\circ}$, the adsorption process is a spontaneous process. Moreover, the increase in temperature which leads to a decrease in the amounts of $\Delta \mathrm{G}^{\circ}$ indicates that the adsorption process is endothermic. Given the values obtained from $\Delta \mathrm{G}^{\circ}$, of between 20 and $0 \mathrm{~kJ} / \mathrm{mol}$, the dominating mechanism in this study is the physisorption mechanism (Table 5). ${ }^{64}$

Table 5. Thermodynamic parameters of dye adsorption on $\mathrm{P}_{2} \mathrm{~W}_{18} @$ MIL-101 (Cr).

\begin{tabular}{lccc}
\hline $\begin{array}{l}\text { Temperature } \\
\text { MB }\end{array}$ & \multicolumn{3}{c}{ Thermodynamic parameters } \\
& $\begin{array}{c}\Delta \mathbf{G}^{\circ} \\
(\mathbf{k J} / \mathbf{m o l})\end{array}$ & $\begin{array}{c}\Delta \mathbf{H}^{\circ} \\
(\mathbf{k J} / \mathbf{m o l})\end{array}$ & $\begin{array}{c}\Delta \mathbf{S}^{\circ} \\
(\mathbf{J} / \mathbf{m o l ~ K})\end{array}$ \\
\hline 25 & -9.63 & 30.52 & 133.02 \\
35 & -10.44 & & \\
45 & -11.78 & & \\
55 & -13.1 & & \\
65 & -14.43 & & \\
75 & -15.76 & & \\
\hline
\end{tabular}

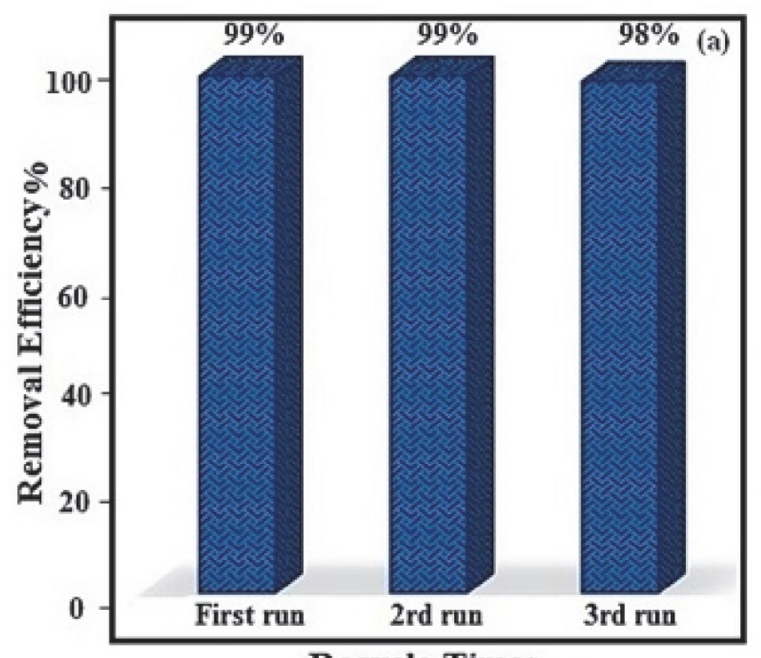

Recycle Times

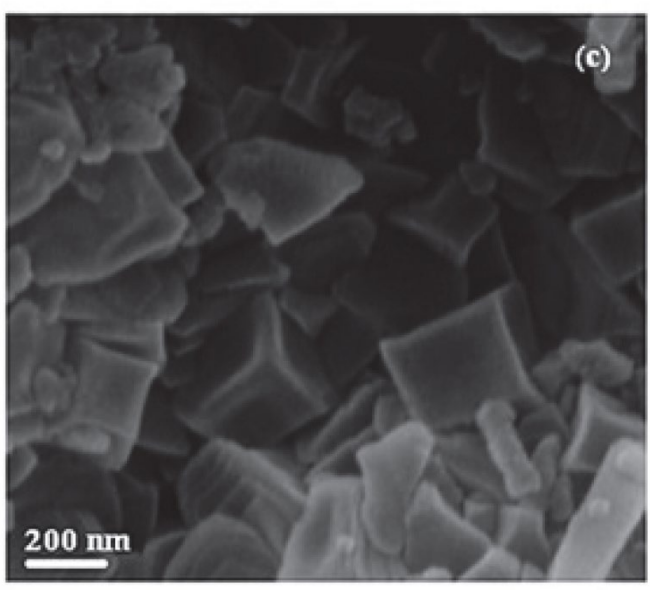

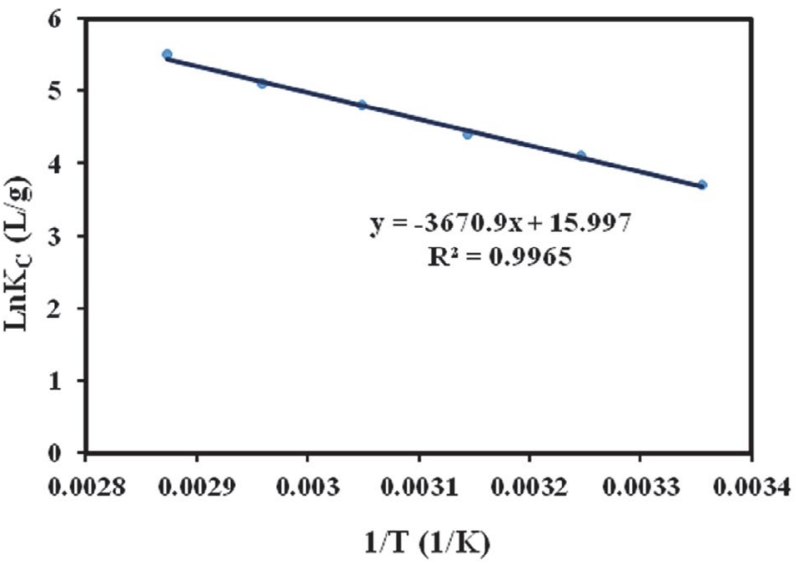

Figure 14. Plots $\ln \mathrm{K}_{\mathrm{C}}$ versus $1 / \mathrm{T}$ for adsorption of dyes.

\section{2. 9. Stability and Recyclability of Hybrid Nanomaterial}

The stability and reusability of $\mathrm{P}_{2} \mathrm{~W}_{18} @ \mathrm{MIL}-101$ (Cr) are important aspects of the practical removal of dye pol-
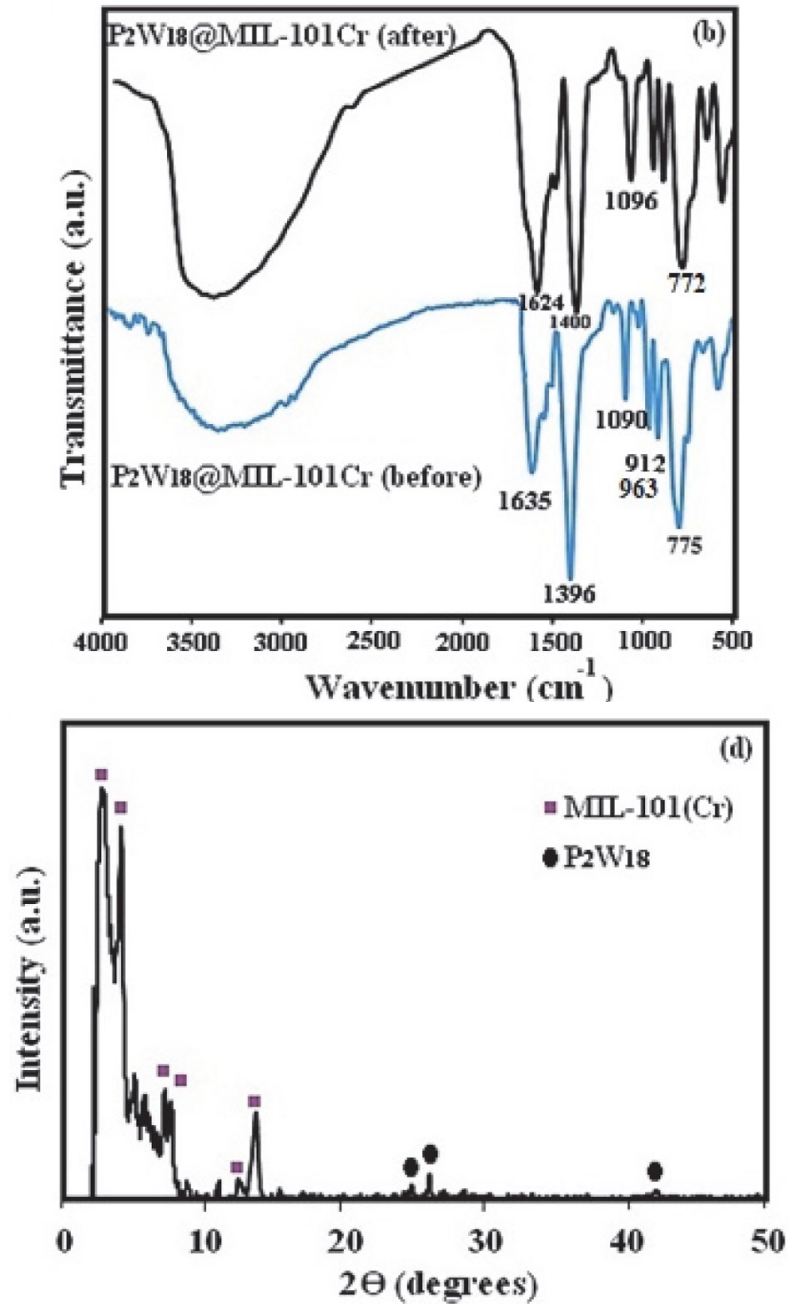

Figure 15. (a) Recycling tests of the nanohybrid toward MB adsorption. (b) FT-IR spectrum before and after adsorption (c) SEM image and (d) XRD pattern of the recovered nanohybrid after 3rd cycle. 
lutants. By using cycle tests, the removing of MB was studied. The adsorbent was separated by centrifugation was completely separated by simple centrifugation due to its insoluble property in water. Following, the fast release process of the adsorbed MB was achieved by thoroughly washing the adsorbent with ethanol, water, and $\mathrm{NaCl}$ mixture several times and dried overnight at $60{ }^{\circ} \mathrm{C}$ and reused for adsorption again under the same condition. As can be seen in Figure 15(a), a slight drop was happened in the removal efficiency after three cycles. This property is significant as it can reduce the cost of the adsorption without the collapse or loss of the structure of the material. Moreover, the $\mathrm{Cr}$ and $\mathrm{W}$ contents in aqueous phase after the separation of adsorbent were analyzed by ICP-AES. No observable leaching of $\mathrm{Cr}$ and $\mathrm{W}(\leq 0.1 \mathrm{wt} \%)$ was observed in the 1 st as well as the $3 \mathrm{rd}$ run of the adsorption. As shown in Figure 15(b)-(d), FT-IR, SEM and XRD pattern of the recycled $\mathrm{P}_{2} \mathrm{~W}_{18} @$ MIL-101 (Cr) adsorbent did not show significantly more changes after the third run compared to the fresh adsorbent. Therefore, these observations confirm that the as-prepared $\mathrm{P}_{2} \mathrm{~W}_{18} @ \mathrm{MIL}-101(\mathrm{Cr})$ ) adsorbent can work as an effective adsorbent for cationic dyes removal with good stability and recyclability.

\section{Conclusions}

In summary, the Dowson-type polyoxometalate@ MIL-101(Cr) metal-organic framework $\left(\mathrm{P}_{2} \mathrm{~W}_{18} @\right.$ MIL$101(\mathrm{Cr}))$ nanohybrid with a high BET specific surface area of $1167.4 \mathrm{~m}^{2} \mathrm{~g}^{-1}$ were successfully prepared by a simple one-pot hydrothermal route. The FT-IR, XRD, and EDX analyses confirmed the successful incorporation of the $\mathrm{P}_{2} \mathrm{~W}_{18}$ in MIL-101 (Cr) framework. This nanohybrid could selectively adsorb cationic dyes because of the presence of $\mathrm{P}_{2} \mathrm{~W}_{18}$ polyanions in its structure and strong interaction with cationic dyes. The results revealed that the adsorption process was followed pseudo-second-order kinetic. Furthermore, the $\mathrm{P}_{2} \mathrm{~W}_{18} @ \mathrm{MIL}-101(\mathrm{Cr})$ nanohybrid could be recycled and reused several times without losing the adsorption capacity. Thus, this material is a promising adsorbent for the treatment of toxic organic pollutants in the colored wastewater.

\section{Acknowledgements}

The authors gratefully acknowledge the Lorestan University for financial support.

\section{References}

1. J. Juan-Alcañiz, E. V. Ramos-Fernandez, U. Lafont, J. Gascon and F. Kapteijn, J. Catal, 2010, 269, 229-241.

DOI:10.1016/j.jcat.2009.11.011
2. K. Ariga, Y. Yamauchi, G. Rydzek, Q. Ji, Y. Yonamine, K. C.W. Wu and J. P. Hill, Chem. Lett., 2013, 43, 36-68. DOI:10.1246/cl.130987

3. K. Ariga, H. Ito, J. P. Hill and H. Tsukube, Chem. Soc. Rev., 2012, 41, 5800-5835. DOI:10.1039/c2cs35162e

4. R. Q. Zou, H. Sakurai and Q. Xu, Angew. Chem. Int. Ed., 2006, 118, 2604-2608. DOI:10.1002/ange.200503923

5. M. Allendorf, C. Bauer, R. Bhakta and R. Houk, Chem. Soc. Rev., 2009, 38, 1330-1352. DOI:10.1039/b802352m

6. M. Kurmoo, Chem. Soc. Rev., 2009, 38, 1353-1379. DOI:10.1039/b804757j

7. M. Li, D. Li, M. O'Keeffe and O. M. Yaghi, Chem. Rev., 2013, 114, 1343-1370. DOI:10.1021/cr400392k

8. A. Aijaz, T. Akita, N. Tsumori and Q. Xu, J. Am. Chem. Soc., 2013, 135, 16356-16359. DOI:10.1021/ja4093055

9. L. Wang, M. Zheng and Z. Xie, J. Mater. Chem. B, 2018, 6, 707-717. DOI:10.1039/C7TB02970E

10. D. Tian, Q. Chen, Y. Li, Y. H. Zhang, Z. Chang and X. H. Bu, Angew. Chem. Int. Ed., 2014, 53, 837-841.

DOI:10.1002/anie.201307681

11. S. Pramanik, C. Zheng, X. Zhang, T. J. Emge and J. Li, J. Am. Chem. Soc., 2011, 133, 4153. DOI:10.1021/ja106851d

12. X. Liu, J. Luo, Y. Zhu, Y. Yang and S. Yang, J. Alloys Compd., 2015, 648, 986-993. DOI:10.1016/j.jallcom.2015.07.065

13. Z.-P. Qi, Y.-S. Kang, F. Guo and W.-Y. Sun, Microporous Mesoporous Mater., 2019, 273, 60-66.

DOI:10.1016/j.micromeso.2018.06.051

14. J. Abdi, N. M. Mahmoodi, M. Vossoughi and I. Alemzadeh, Microporous Mesoporous Mater., 2019, 273, 177-188.

DOI:10.1016/j.micromeso.2018.06.040

15. J. Li, J.-L. Gong, G.-M. Zeng, P. Zhang, B. Song, W.-C. Cao, H.-Y. Liu and S.-Y. Huan, J. Colloid Interface Sci., 2018, 527, 267-279. DOI:10.1016/j.jcis.2018.05.028

16. S.-N. Zhao, C. Krishnaraj, H. S. Jena, D. Poelman and P. Van Der Voort, Dyes Pigments, 2018, 156, 332-337.

DOI:10.1016/j.dyepig.2018.04.023

17. S. Qiu, M. Xue and G. Zhu, Chem. Soc. Rev., 2014, 43, 61166140. DOI:10.1039/C4CS00159A

18. E. D. Bloch, W. L. Queen, R. Krishna, J. M. Zadrozny, C. M. Brown, J. R. Long, Science, 2012, 335, 1606-1610.

DOI:10.1126/science.1217544

19. F.-J. Ma, S.-X. Liu, C.-Y. Sun, D.-D. Liang, G.-J. Ren, F. Wei, Y.-G. Chen and Z.-M. Su, J. Am. Chem. Soc., 2011, 133, 41784181. DOI:10.1021/ja109659k

20. H. N. Miras, J. Yan, D.-L. Long and L. Cronin, Chem. Soc. Rev., 2012, 41, 7403-7430. DOI:10.1039/c2cs35190k

21. A. Sakthivel, K. Komura, Y. Sugi, Ind. Eng. Chem. Res. 2008, 47, 2538 -2544. DOI:10.1021/ie071314z

22. A. E. R. S. Khder, H. Hassan, M. S. El-Shall, Appl. Catal. A 2012, 411, 77-86. DOI:10.1016/j.apcata.2011.10.024

23. H. N. Miras, J. Yan, D.-L. Long and L. Cronin, Chem. Soc. Rev., 2012, 41, 7403-7430.

DOI:10.1039/c2cs35190k

24. X. L. Hao, Y. Y. Ma, H. Y. Zang, Y. H. Wang, Y. G. Li and E. B. Wang, Chem. Eur. J., 2015, 21, 3778-3784.

DOI:10.1002/chem.201405825 
25. X.-B. Han, Z.-M. Zhang, T. Zhang, Y.-G. Li, W. Lin, W. You, Z.-M. Su and E.-B. Wang, J. Am. Chem. Soc., 2014, 136, 53595366. DOI:10.1021/ja412886e

26. A. X. Yan, S. Yao, Y. G. Li, Z. M. Zhang, Y. Lu, W. L. Chen and E. B. Wang, Chem. Eur. J., 2014, 20, 6927-6933.

DOI:10.1002/chem.201400175

27. X. L. Hao, Y. Y. Ma, H. Y. Zang, Y. H. Wang, Y. G. Li and E. B. Wang, Chem. Eur. J., 2015, 21, 3778-3784.

DOI:10.1002/chem.201405825

28. F.-Y. Yi, W. Zhu, S. Dang, J.-P. Li, D. Wu, Y.-H. Li and Z.-M. Sun, Chem. Commun., 2015, 51, 3336-3339. DOI:10.1039/C4CC09569C

29. C. T. Buru, P. Li, B. L. Mehdi, A. Dohnalkova, A. E. Platero-Prats, N. D. Browning, K. W. Chapman, J. T. Hupp and O. K. Farha, Chem. Mater., 2017, 29, 5174-5181. DOI:10.1021/acs.chemmater.7b00750

30. I. Ahmed and S. H. Jhung, Mater. Today, 2014, 17, 136-146. DOI:10.1016/j.mattod.2014.03.002

31. X.-L. Hao, Y.-Y. Ma, C. Zhang, Q. Wang, X. Cheng, Y.-H. Wang, Y.-G. Li and E.-B. Wang, CrystEngComm, 2012, 14, 6573-6580. DOI:10.1039/c2ce25747e

32. L. Bromberg, Y. Diao, H. Wu, S. A. Speakman and T. A. Hatton, Chem. Mater., 2012, 24, 1664-1675.

DOI:10.1021/cm2034382

33. I.-M. Mbomekalle, Y. W. Lu, B. Keita and L. Nadjo, Inorg. Chem. Commun., 2004, 7, 86-90.

DOI:10.1016/j.inoche.2003.10.011

34. X. Hu, Y. Lu, F. Dai, C. Liu and Y. Liu, Microporous Mesoporous Mater., 2013, 170, 36-44.

DOI:10.1016/j.micromeso.2012.11.021

35. N. V. Maksimchuk, O. A. Kholdeeva, K. A. Kovalenko and V. P. Fedin, Isr. J. Chem., 2011, 51, 281-289. DOI:10.1002/ijch.201000082

36. C. Roch-Marchal, T. Hidalgo, H. Banh, R. A. Fischer and P. Horcajada, Eur. J. Inorg. Chem., 2016, 2016, 4387-4394.

37. T.-T. Zhu, Z.-M. Zhang, W.-L. Chen, Z.-J. Liu and E. B. Wang, RSC Adv., 2016, 6, 81622-81630.

38. B. Hong, L. Liu, S.-M. Wang and Z.-B. Han, J. Clust. Sci., 2016, 27, 563-571.

39. L. Zhang, B. Shan, H. Yang, D. Wu, R. Zhu, J. Nie and R. Cao, RSC Adv., 2015, 5, 23556-23562

40. Y. Zhang, V. Degirmenci, C. Li and E. J. Hensen, ChemSusChem., 2011, 4, 59-64. DOI:10.1002/cssc.201000284

41. N. M. Mahmoodi, J. Taiwan. Inst. Chem. Eng., 2013, 44, 322-330. DOI:10.1016/j.jtice.2012.11.014

42. N. M. Mahmoodi, U. Sadeghi, A. Maleki, B. Hayati and F. Najafi, J. Ind. Eng. Chem., 2014, 20, 2745-2753.

DOI:10.1016/j.jiec.2013.11.002

43. J. Lee, O. K. Farha, J. Roberts, K. A. Scheidt, S. T. Nguyen and J. T. Hupp, Chem. Soc. Rev., 2009, 38, 1450-1459.

DOI:10.1039/b807080f
44. J.-R. Li, R. J. Kuppler and H.-C. Zhou, Chem. Soc. Rev., 2009, 38, 1477-1504. DOI:10.1039/b802426j

45. T. K. Trung, P. Trens, N. Tanchoux, S. Bourrelly, P. L. Llewellyn, S. Loera-Serna, C. Serre, T. Loiseau, F. Fajula and G. Férey, J. Am. Chem. Soc., 2008, 130, 16926-16932. DOI:10.1021/ja8039579

46. S.-I. Noro, R. Kitaura, M. Kondo, S. Kitagawa, T. Ishii, H. Matsuzaka and M. Yamashita, J. Am. Chem. Soc., 2002, 124, 2568-2583. DOI:10.1021/ja0113192

47. L. Yao, L. Zhang, R. Wang, S. Chou and Z. Dong, J. Hazard. Mater., 2016, 301, 462-470.

DOI:10.1016/j.jhazmat.2015.09.027

48. R. Li, X. Q. Ren, J. S. Zhao, X. Feng, X. Jiang, X. X. Fan, Z. G. Lin, X. G. Li, C. G. Hu, and B. Wang, J. Mater. Chem. A, 2014, 2, 2168-2173. DOI:10.1039/C3TA14267A

49. S. Farhadi, F. Mahmoudi, M. M. Amini, M. Dusek and M. Jarosova, Dalton Trans., 2017, 46, 3252-3264. DOI:10.1039/C6DT04866H

50. H. Sun, L. Cao and L. Lu, Nano Res., 2011, 4, 550-562. DOI:10.1007/s12274-011-0111-3

51. Z. Jiang and Y. Li, J. Taiwan. Inst. Chem. Eng., 2016, 59, 373379. DOI:10.1016/j.jtice.2015.09.002

52. C. Yang, J. Cheng, Y. Chen and Y. Hu, J. Colloid Interface Sci., 2017, 504, 39-47. DOI:10.1016/j.jcis.2017.05.020

53. S. M. Humphrey and P. T. Wood, J. Am. Chem. Soc., 2004, 126, 13236-13237. DOI:10.1021/ja046351l

54. N. M. Mahmoodi, B. Hayati and M. Arami, Ind Crop Prod., 2012, 35, 295-301. DOI:10.1016/j.indcrop.2011.07.015

55. N. M. Mahmoodi, B. Hayati, M. Arami and C. Lan, Desalination, 2011, 268, 117-125. DOI:10.1016/j.desal.2010.10.007

56. J. An, S. J. Geib and N. L. Rosi, J. Am. Chem. Soc., 2009, 131, 8376-8377. DOI:10.1021/ja902972w

57. G. Férey, Chem. Soc. Rev., 2008, 37, 191-214. DOI:10.1039/B618320B

58. J. D. Joshi, N. B. Patel and S. D. Patel, Iran Polym J., 2006, 15, 219.

59. K. A. Cychosz, A. G. Wong-Foy and A. J. Matzger, J. Am. Chem. Soc., 2008, 130, 6938-6939. DOI:10.1021/ja802121u

60. Y. Kim, C. Kim, I. Choi, S. Rengaraj and J. Yi, Environ. Sci. Technol., 2004, 38, 924-931. DOI:10.1021/es0346431

61. Z. A. Lethbridge, J. J. Williams, R. I. Walton, K. E. Evans and C. W. Smith, Microporous Mesoporous Mater., 2005, 79, 339352. DOI:10.1016/j.micromeso.2004.12.022

62. F. Di Renzo, Catal. Today, 1998, 41, 37-40. DOI:10.1016/S0920-5861(98)00036-4

63. T. O. Drews and M. Tsapatsis, Curr. Opin. Colloid Interface Sci, 2005, 10, 233-238. DOI:10.1016/j.cocis.2005.09.013

64. W. J. Rieter, K. M. Taylor and W. Lin, J. Am. Chem. Soc., 2007, 129, 9852-9853. DOI:10.1021/ja073506r 


\section{Povzetek}

V ogrodje kovinsko-organskega poroznega materiala (MOF, MIL-101(Cr)) smo uspešno vgradili sol $\mathrm{K}_{6} \mathrm{P}_{2} \mathrm{~W}_{18} \mathrm{O}_{62}(\mathrm{skraj-}$ šano $\mathrm{P}_{2} \mathrm{~W}_{18}$ ). Nano-hibrid $\mathrm{P}_{2} \mathrm{~W}_{18} @ \mathrm{MIL}-101(\mathrm{Cr})$ smo karakterizirali z infrardečo spektroskopijo, rentgensko difrakcijo (XRD), ramansko spektroskopijo, energijsko disperzijsko spektroskopijo rentgenskih žarkov EDX, vrstično elektronsko mikroskopijo (SEM), meritvami zeta potenciala in meritvami površine (BET). Glede na rezultate lahko ocenimo, da se je $\mathrm{K}_{6} \mathrm{P}_{2} \mathrm{~W}_{18} \mathrm{O}_{62}(\sim 36$ ut.\%) vgradil v porozni okvir MIL-101(Cr). V primerjavi s čistim MIL-101(Cr) sta v vzorcu $\mathrm{P}_{2} \mathrm{~W}_{18} @ \mathrm{MIL}-101(\mathrm{Cr})$ znatno zmanjšana površina in volumen por zaradi vgraditve velike soli $\mathrm{K}_{6} \mathrm{P}_{2} \mathrm{~W}_{18} \mathrm{O}_{62} \mathrm{v}$ kletke $\mathrm{MO}$ Fa. $\mathrm{P}_{2} \mathrm{~W}_{18} @ \mathrm{MIL}-101(\mathrm{Cr})$ smo uporabili kot nov adsorbent za odstranjevanje barvil metilen modro (MB), rodamine B $(\mathrm{RhB})$ in metiloranž (MO) iz vodnih raztopin. V tem delu študije smo preučevali učinek parametrov, kot so odmerjanje adsorbenta, koncentracija barvila, $\mathrm{pH}$ in temperatura, na postopek odstranjevanja barvil. Poleg tega smo učinkovitost in selektivnost adsorpcije preučevali tudi v raztopinah mešanice barvil $\mathrm{MB} / \mathrm{MO}, \mathrm{MB} / \mathrm{RhB}, \mathrm{MO} / \mathrm{RhB}$ in $\mathrm{MB} / \mathrm{MO} / \mathrm{RhB}$. $\mathrm{P}_{2} \mathrm{~W}_{18} @ \mathrm{MIL}-101(\mathrm{Cr})$ je hitro in selektivno adsorbiral kationski barvili MB in RhB iz mešanice raztopin barvil. Glede na termodinamske podatke je adsorpcija barvila endotermni proces. $\mathrm{P}_{2} \mathrm{~W}_{18} @ \mathrm{MIL}-101(\mathrm{Cr})$ je lahko učinkovit adsorbent, ki ga je mogoče reciklirati in je uporaben za hitro odstranjevanje različnih kationskih tekstilnih barvil iz vodnih raztopin. 